\title{
ДОРОЖНО-ТРАНСПОРТНЫЕ ПРОИСШЕСТВИЯ И СМЕРТНОСТЬ В РОССИИ: 1956-2012
}

\author{
ТИМУР ФAТТАХОВ
}

\begin{abstract}
В статье впервые представлен анализ непрерывных статистических данных о смертности от ДТП в России с 1956 г. Общее число погибших за 1956-2012 г2. превысило 1,4 млн. Рост смертности от ДТП начался в 1970-е годы, с начала 1990-х годов нарастает отставание от большинства развитых стран. При уровнях смертности 2012 г. примерно 85-95\% российских смертей от ДТП-избыточны по сравнению с тем числом, которое могло бы быть при уровне возрастной смертности от этой причины в ряде европейских стран. Как нынешние характеристики общего уровня автомобилизащии, так и основные показатели транспортного травматизма, такие как число погибших на 100 тыс. населения, на 10 тыс. транспортных средств или на километраж автопробега, свидетельствуют о том, что Россия по уровню транспортного развития отстает от стран Запада на 40-50 лет.

В статье рассматривается также история включения смертности от ДТП в Международную классификацию причин смерти (МКБ) и вопросы отражения этой смертности в российской статистике. Проанализированы половозрастные особенности и тенденции российской смертности от ДТП, различия в смертности по разным категориям участников дорожного движения (водители, пассажиры и пешеходы) за максимально возможный период. Представлены международные сравнения и сопоставления, которые позволяют понять масштабы российского отставания $и$ увидеть долгосрочные неустойчивые тенденции в смертности от ДТП.
\end{abstract}

Делается вывод о необходимости расширения научных исследований проблем дорожнотранспортной безопасности без чего невозможна разработка эффективных программ повымения этой безопасности и преодоление отставания от многих опередивших Россию стран.

Ключевые слова: автомобилизация, дорожно-транспортные происшествия (ДТП), история ДТП, погибшие в ДТП, Международный классификатор болезней (МКБ), внешние причинь смерти.

\section{ИСТОРИЯ ДОРОЖНО-ТРАНСПОРТНЫХ ПРОИСШЕСТВИЙ}

Дорожно-транспортные происшествия (ДТП) - относительно молодая причина смерти. Убийства, самоубийства, отравления, утопления существовали всегда, но о ДТП этого сказать нельзя, они - порождение новой техногенной эпохи [Вишневский, Фаттахов 2012].

Правда, первые упоминания о транспортных опасностях относятся к временам глубокой древности. Древнегреческий миф о Фаэтоне, который не справился с управлением отцовской колесницей, говорит о том, что люди издавна знали о рисках, связанных с управлением колесным транспортом. Существует предположение, впрочем небесспорное, что 19-летний фараон Тутанхамон, правивший Египтом в XIV веке до н.э., погиб от травм, полученных при падении с колесницы во время охоты. В Библии имеется упоминание о падении сирийского царя Антиоха IV Епифана: «Тогда случилось, что он упал с колесницы, которая неслась быстро, и тяжким падением повредил все члены тела» [Библия... 2015]. Марк Валерий Марциал (ок. 40-104 г.), римский поэт-эпиграммист, приводит историю о древнегреческом гонщике Скорпусе, который выиграл более 2000 соревнований и погиб в заезде в возрасте 27 лет [Марциал 1968].

ФАТТАХОВ ТИМУР АСФАНОВИЧ, ИНСТИТУТ ДЕМОГРАФИИ НАЦИОНАЛЬНОГО ИССЛЕДОВАТЕЛЬСКОГО УНИВЕРСИТЕТА «ВЫСШАЯ ШКОЛА ЭКОНОМИКИ». РОССИЯ. E-mail: tfattahov@hse.ru СТАТЬЯ ПОСТУПИЛА В РЕДАКЦИЮ В ФЕВРАЛЕ 2015 Г. 
Знакомы были древним и проблемы дорожного движения, и было немало попыток его регулировать. Например, Юлий Цезарь в законе о городском благоустройстве (45 г. до н.э.) запретил всякому конному транспорту въезд в Рим после солнечного восхода и до заката. Исключение было сделано только для телег, которые ввозили строительные материалы для храмов и общественных зданий и вывозили из города мусор, а также для триумфальных колесниц и повозок, ехавших в торжественных процессиях. В I-II веках это запрещение было распространено на все города Италии. Император Клавдий эдиктом запретил проезжать через италийские города в повозках; Марк Аврелий также подтвердил это запрещение [Сергеенко 2000]. Но, видимо, это помогало мало. Ювенал (ок. 60-127 гг.) описывает в одной из своих сатир движение по римским улицам [Ювенал 2015]:

Телеги едут по узким

Улии извивам, и брань сльишна у стоящих обозов $<\ldots>\ldots$

Если богач спешит по делам, - над толпы головами,

Всех раздвинув, его понесут на просторной либурне;

Там ему можно читать, писать или спать по дороге <... >, -

Все же поспеет он в срок; а нам, спешащим, мешает

Люд впереди, и мнет нам бока огромной толпою

Сзади идущий народ: этот локтем толкнет, а тот палкой

Крепкой, иной по башке тебе даст бревном иль бочонком;

Ноги у нас все в грязи, наступают большие подошвь

С разных сторон, и вонзается в пальиьы военная шпора $<\ldots>$

Туники рвутся, едва зачиненные; елку шатает

С ходом телеги, сосну привезла другая повозка;

Длинных деревьев шатанье с высот угрожает народу.

Если сломается ось, что везет Лигурийские камни

И над толпой разгрузит эту гору, ее опрокинув, -

Что остается от тел? кто члены и кости отыщет?

Касательно некоторых средневековых дорог законодатели того времени сами признавали, что по ним можно ездить лишь с опасностью для жизни, а в письмах купцов $\mathrm{XV}$ века подчеркивается особо, что из-за состояния дорог и других опасностей тот или другой с трудом вернулся из поездки невредимым [Кулишер 2012]. Эта проблема была известна и в России. Есть упоминания о том, что на Руси в XV веке были введены первые общие правила пользования почтовыми трактами. В начале XVIII века Петром I был издан указ, в котором давались предписания, как необходимо вести себя при езде по городу, а контроль за исполнением общих правил движения возлагался на полицию [Золотая книга... 2006].

К концу XIX века в Европе достигло своего пика развитие экипажного дела. По ориентировочным подсчетам, мировой гужевой парк в последние десятилетия XIX века достиг 20 млн транспортных средств [Долматовский 1986], что, безусловно, оказывало влияние на масштабы транспортного травматизма. Так, с участием гужевого транспорта в Великобритании в 1875 г. погибло 1589 человек [Cummins 2003]. В Нью-Йорке в 1900 г. изза лошадей и повозок погибло 200 человек, в 2012 г. там же в ДТП погибло 293 человека. Население Нью-Йорка в 1900 г. составляло 3,4 млн человек, в 2010 г. - 8,2 млн, получается, что уровень смертности на 100 тыс. населения в ДТП в начале века был примерно на $40 \%$ выше, чем сейчас [Morris 2007]. 
Тем не менее источником повсеместной массовой опасности для жизни и здоровья людей на улицах и дорогах колесный транспорт стал только после появления автомобиля. Первый в мире автомобиль был создан в 1886 г., а первое в мире ДТП с участием автомобиля (наезд на пешехода) случилось через 10 лет (в 1896 г.). С 1899 г. начался отсчет ДТП с участием автомобиля, приведших к трагическому исходу.

С тех пор число ДТП, к сожалению, постоянно растет. В них разбиваются машины, получают травмы и гибнут люди. По числу жертв в мире ДТП считаются одной из наиболее опасных внешних причин смерти. Кроме того, это очень важная причина инвалидизации населения, так как на один случай смерти от ДТП приходится во много раз больше выживших, но получивших травмы [Вишневский 2010]. Еще в 1974 г. на 27-й Всемирной ассамблее здравоохранения была принята резолюцию, в которой объявлялось, что ДТП являются одной из важнейших проблем здравоохранения [WHA 27/59].

В России процесс автомобилизации начался в период, когда в развитых странах мира уже существовали сотни тысяч автомобилей. Первые автомобили в России появились в начале XX века. До начала 1970-х годов количество производимых легковых автомобилей уступало количеству грузовиков, что было совершенно нетипично для стран с высоким уровнем автомобилизации. Перелом наступил только после ввода в эксплуатацию в 1971 г. Волжского автомобильного завода (ВАЗ) в Тольятти. Если в 1970 г. в России было выпущено 257 тыс. легковых автомобилей и 445 тыс. грузовиков, то уже в 1975 г. соотношение было совершенно иным: 1066 тыс. легковых автомобилей и 591 тыс. грузовых. С этого времени начались постепенное насыщение рынка легковыми автомобилями и реальная, хотя вначале и довольно медленная, автомобилизация СССР и России (рисунок 1).

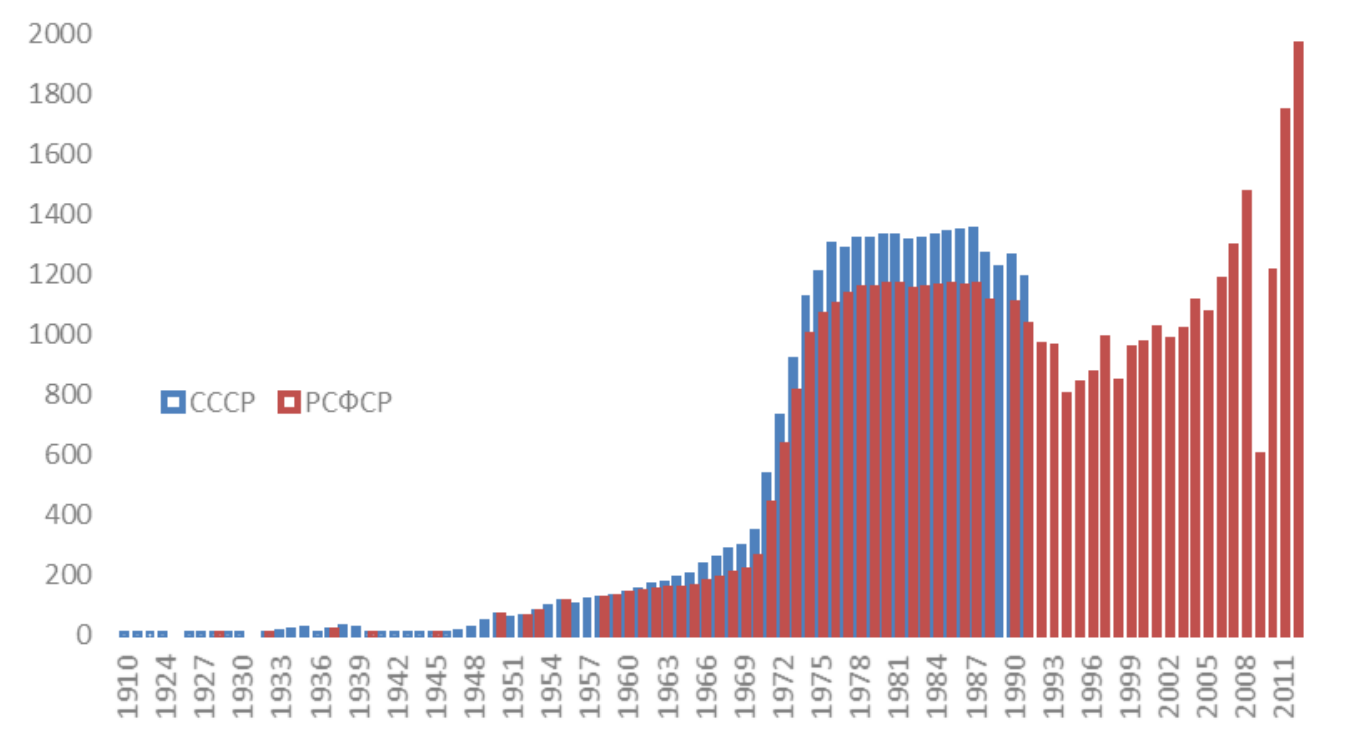

Рисунок 1. Производство легковых автомобилей в СССР и в России, тыс.

Источники: [Народное хозяйство ... 1958-1990; Росстат 1990-2013].

В 2012 г. в России парк легковых автомобилей составил 38,7 млн единиц. С 2000 по 2012 г. доля легковых автомобилей в структуре автопарка выросла с 64,6 до 80,9\% (рисунок 2). 


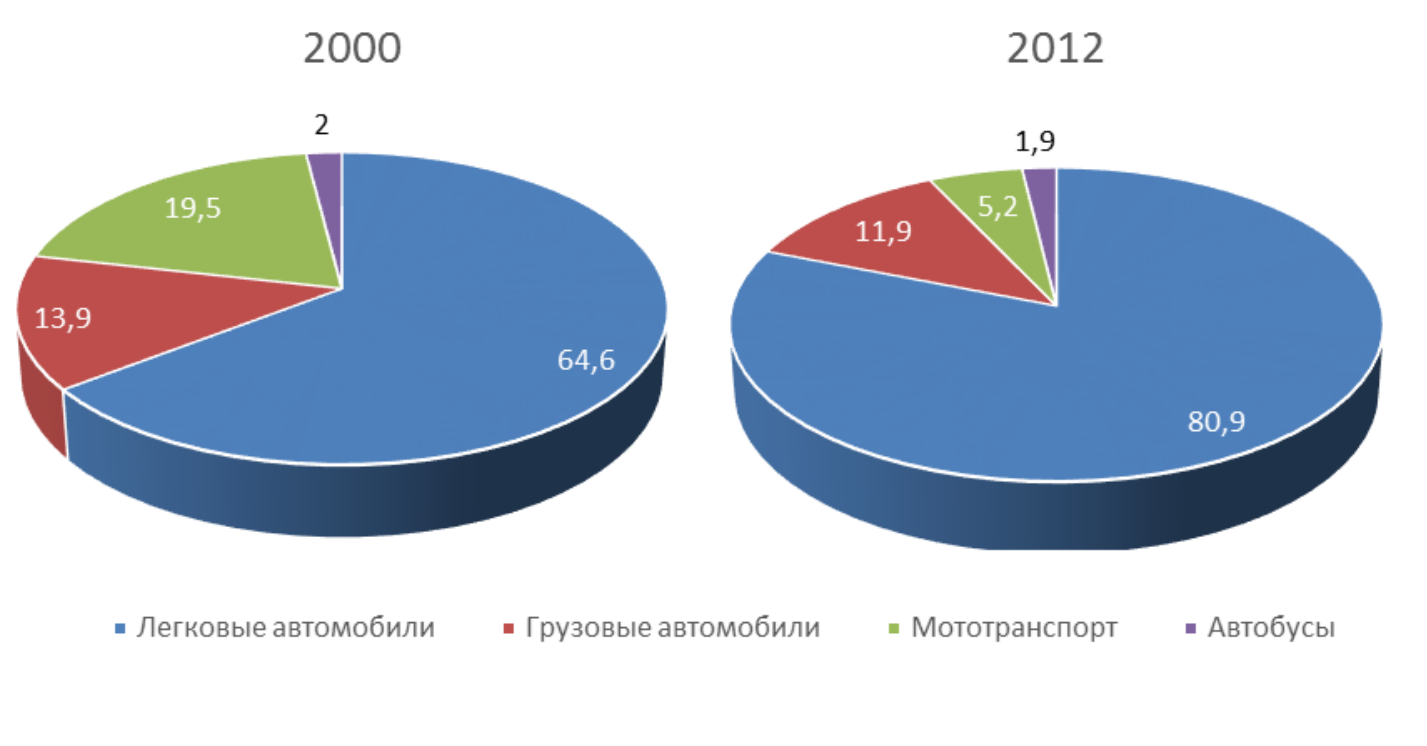

Рисунок 2. Структура российского автопарка в 2000, 2012 г., \%

Источник: [ГИБДД...].

Рост автомобильного парка в последние десятилетия происходит в значительной степени за счет иностранных автомобилей. Так, если в 1999 г. в России насчитывалось всего 4,2 млн единиц иномарок, то в 2012 г. - уже 17,7 млн (рисунок 3). В 1999 г. лишь каждый пятый легковой автомобиль в стране был иностранного производства, в 2012 г. - почти каждый второй $(45,6 \%)$.

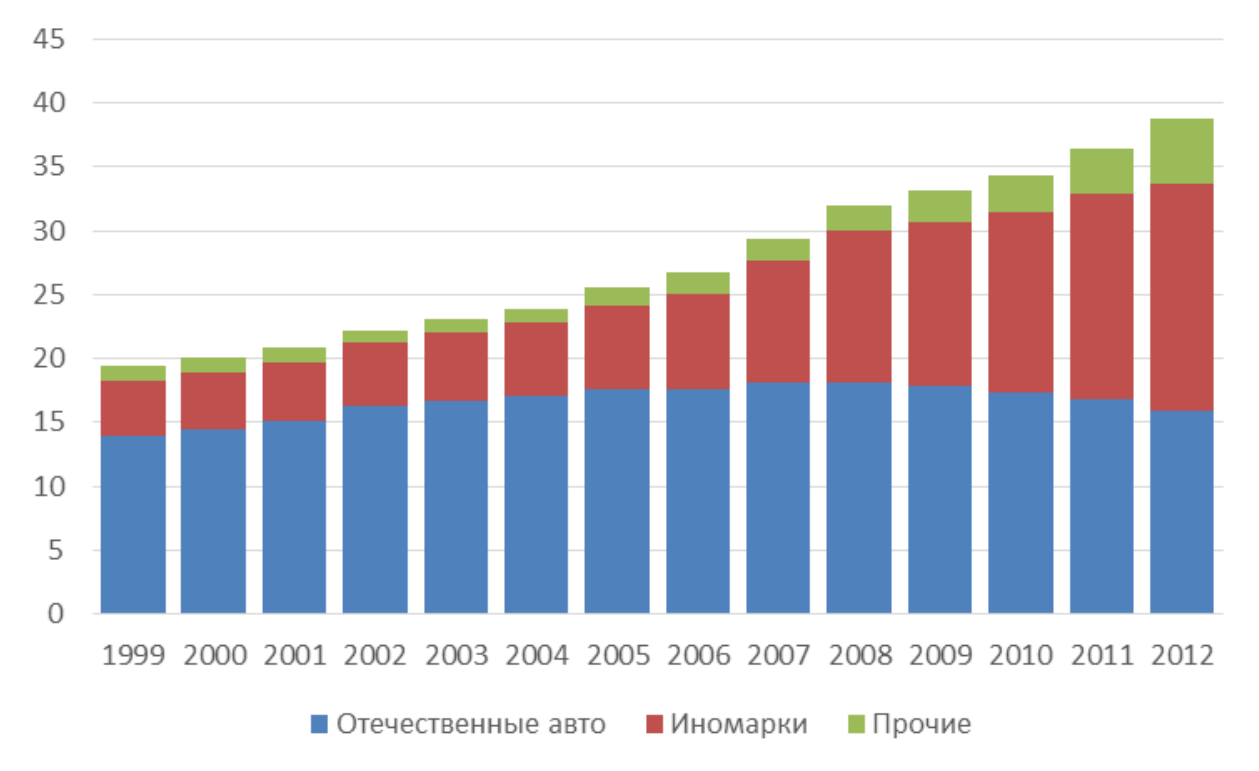

Рисунок 3. Рост парка легковых автомобилей в России в 1999-2012 гг., млн

Источник: [ГИБДД...].

С начала 70-х годов стало возрастать и значение дорожно-транспортного травматизма в общей структуре смертности. Дорожно-транспортный травматизм, конечно, имел место в России и до этого, но связанные с ним потери были несопоставимы со значениями, каких он достиг 20-30 лет спустя, несмотря на все еще относительно низкий, 
по мировым меркам, уровень моторизации. Как писали авторы статьи о последствиях ДТП в России еще в начале 2000-х годов, когда число легковых автомобилей на 1000 жителей не достигало и 150, «создается впечатление, что Россия задалась целью компенсировать малое число автомобилей большим числом погибших в расчете на каждый из них» [Ревич, Решетников 2001]. С тех пор число легковых автомобилей на 1000 жителей в России удвоилось, а проблема ДТП и их последствий, в том числе и смертности от них, приобрела еще большее значение.

\section{ДТП В МЕЖДУНАРОДНОЙ КЛАССИФИКАЦИИ БОЛЕЗНЕЙ И РОССИЙСКОЙ НОМЕНКЛАТУРЕ ПРИЧИН СМЕРТИ}

Осознание значимости дорожно-транспортного травматизма как фактора, влияющего на здоровье, и как причины смерти можно проследить в Международной классификации болезней, травм и причин смерти (МКБ). Это осознание пришло не сразу. В первой редакции МКБ, принятой в 1900 г., в разделе «Насильственные смерти» транспортные происшествия, включая ДТП, не выделялись особо, а включались в группу «Другие внешние причины», что вполне объяснимо. Роль автотранспорта как источника опасности для здоровья и жизни тогда была еще незначительной, люди в основном погибали под колесами карет, дилижансов и повозок.

В следующих редакциях (МКБ-2 и МКБ-3) ДТП также еще не были выделены в отдельную причину смерти, в разделе «Насильственные смерти» выделялась причина, которая объединяла транспортные происшествия с некоторыми природными катаклизмами: «Травмы и другие увечья (автомобили, железные дороги, водный транспорт, оползни и т.д.)» [Международная статистическая...].

В МКБ-4 транспортные происшествия не попали в основной список причин заболеваний и смерти, но были рекомендованы как причины, по которым необходимо вести отдельный учет. Рекомендовалось выделять отдельно: железнодорожный транспорт; автомобили и мотоциклы; другие перевозочные средства; водный транспорт и воздушный транспорт.

В МКБ-5 (1938 г.), были введены значительные изменения. Впервые появился раздел, связанный с транспортными происшествиями. Он включал 9 причин, одна из которых была обозначена как ДТП:

- железнодорожные аварии (любые причины смерти, кроме войны);

- ДТП (любые причины смерти, кроме войны);

- столкновения с поездами;

- столкновения с трамваями;

- другие автомобильные аварии;

- аварии с трамваями на дорогах (любые причины смерти, кроме войны);

- другие ДТП на дороге (любые причины смерти, кроме войны);

- аварии на водном транспорте (любые причины смерти, кроме войны);

- воздушные транспортные происшествия (любые причины смерти, кроме войны) [Международная статистическая...]. 
Таблица 1. Классификация транспортных происшествий в МКБ-1 - МКБ-5

\begin{tabular}{|c|c|c|}
\hline & Транспортные происшествия & ДТП \\
\hline МКБ-1 (1900 г.) & $\begin{array}{l}\text { Отдельно не выделяются. Транспортные } \\
\text { происшествия входят в состав причины } 166 \text { «Другие } \\
\text { внешние причины» }\end{array}$ & Не выделялись \\
\hline МКБ-2 (1909 г.) & $\begin{array}{l}\text { Отдельно не выделяются. Транспортные } \\
\text { происшествия входят в состав причины } 175 \text { «Травмы, } \\
\text { полученные в авариях (автомобили, железные } \\
\text { дороги, речной транспорт, оползни и т.д.)» }\end{array}$ & Не выделялись \\
\hline МКБ-3 (1920 г.) & $\begin{array}{l}\text { Отдельно не выделяются. Транспортные } \\
\text { происшествия входят в состав причины } 188 \text { «Травмы, } \\
\text { полученные в авариях (автомобили, железные } \\
\text { дороги, речной транспорт, оползни и т.д.)» }\end{array}$ & Не выделялись \\
\hline МКБ-4 (1929 г.) & $\begin{array}{l}\text { Отдельно не выделяются, но существует } \\
\text { рекомендация о необходимости учета таких } \\
\text { происшествий }\end{array}$ & $\begin{array}{l}\text { Отдельно не выделяются, но } \\
\text { существует рекомендация о } \\
\text { необходимости учета таких } \\
\text { происшествий }\end{array}$ \\
\hline МКБ-5 (1938 г.) & Выделены в отдельные коды (169-173) & $\begin{array}{l}\text { Выделены в отдельные коды } \\
(170-171)\end{array}$ \\
\hline
\end{tabular}

При последующих пересмотрах МКБ, производившихся уже в послевоенный период, значение автомобиля как источника серьезной опасности для здоровья и жизни осознано достаточно ясно, в 6-9-й редакциях присутствует отдельная группа причин смерти и повреждений здоровья, обусловленных транспортными происшествиями («Автомобильные аварии»; таблица 2).

Таблица 2. Классификация транспортных происшествий в МКБ-6 - МКБ-9

\begin{tabular}{|c|c|c|c|}
\hline МКБ-6 (1948 г.) & МКБ-7 (1955 г.) & МКБ-8 (1965 г.) & МКБ-9 (1975 г.) \\
\hline $\begin{array}{l}\text { Аварии на железной } \\
\text { дороге (E800-E802) }\end{array}$ & $\begin{array}{l}\text { Аварии на железной } \\
\text { дороге (E800-E802) }\end{array}$ & $\begin{array}{l}\text { Аварии на железной } \\
\text { дороге (E800-E807) }\end{array}$ & $\begin{array}{l}\text { Аварии на железной } \\
\text { дороге (E800-E807) }\end{array}$ \\
\hline $\begin{array}{l}\text { Автомобильные аварии } \\
\text { (Е810-Е835) }\end{array}$ & $\begin{array}{l}\text { Автомобильные аварии } \\
\text { (Е810-Е835) }\end{array}$ & $\begin{array}{l}\text { Автомобильные аварии } \\
\text { (Е810-Е823) }\end{array}$ & $\begin{array}{l}\text { Автомобильные аварии } \\
\text { (Е810-Е825) }\end{array}$ \\
\hline Другие несчастные & Другие несчастные & Другие несчастные & Другие несчастные \\
\hline случаи (E840-E845) & случаи (Е840-E845) & случаи (Е825-E827) & случаи (Е826-E829) \\
\hline $\begin{array}{l}\text { Аварии на водном } \\
\text { транспорте (Е850-E858) }\end{array}$ & $\begin{array}{l}\text { Аварии на водном } \\
\text { транспорте (Е850-E858) }\end{array}$ & $\begin{array}{l}\text { Аварии на водном } \\
\text { транспорте (Е830-E838) }\end{array}$ & $\begin{array}{l}\text { Аварии на водном } \\
\text { транспорте (Е830-E838) }\end{array}$ \\
\hline $\begin{array}{l}\text { Аварии на воздушном } \\
\text { транспорте (Е860-E866) }\end{array}$ & $\begin{array}{l}\text { Аварии на воздушном } \\
\text { транспорте (E860-E866) }\end{array}$ & $\begin{array}{l}\text { Аварии на воздушном } \\
\text { транспорте (Е840-E845) }\end{array}$ & $\begin{array}{l}\text { Аварии на воздушном } \\
\text { транспорте (Е840-E845) }\end{array}$ \\
\hline
\end{tabular}

В ныне действующей МКБ-10 ДТП занимают центральное место в рубрике «Транспортные несчастные случаи» (V01-V99) класса XX «Внешние причины заболеваемости и смертности», им отведено 8 из 12 групп этой рубрики.

Группы, которые относятся к несчастным случаям, связанным с наземным транспортом (V01-V89), указывают вид транспорта и категорию пострадавшего; кроме того, они имеют подразделы для идентификации другого участника или типа происшествия.

Коды для большинства транспортных несчастных случаев построены на определенном использовании знаков в коде с набором признаков. Первая буква «V» обозначает транспортные несчастные случаи. Второй знак дает информацию о пострадавшем (0 - пешеход, 1 - велосипедист, 2 - мотоциклист и т.д.). Третий знак кода указывает на то, с чем пострадавший столкнулся (01 - с велосипедом, 02 - с двух- или 
трехколесным моторным транспортным средством и т.д.). Сведения о том, что транспортный несчастный случай дорожный или недорожный, идентифицируются на уровне четвертого знака.

Например: Код V03.1 означает, что произошел транспортный несчастный случай (V), в котором столкнулся пешеход (0) с легковым автомобилем (3), дорожный несчастный случай (1).

Таблица 3. Структура транспортных несчастных случаев в МКБ-10

\begin{tabular}{l|l}
\hline V01-V09 & Пешеход, пострадавший в результате транспортного несчастного случая \\
V10-V19 & Велосипедист, пострадавший в результате транспортного несчастного случая \\
V20-V29 & Мотоциклист, пострадавший в результате транспортного несчастного случая \\
V30-V39 & Лицо, находившееся в трехколесном транспортном средстве и пострадавшее в результате \\
& транспортного несчастного случая \\
V40-V49 & $\begin{array}{l}\text { Лицо, находившееся в легковом автомобиле и пострадавшее в результате транспортного } \\
\text { несчастного случая }\end{array}$ \\
V50-V59 & $\begin{array}{l}\text { Лицо, находившееся в грузовом автомобиле типа пикап или фургоне и пострадавшее в } \\
\text { результате транспортного несчастного случая }\end{array}$ \\
V60-V69 & $\begin{array}{l}\text { Лицо, находившееся в тяжелом грузовом автомобиле и пострадавшее в результате } \\
\text { транспортного несчастного случая }\end{array}$ \\
V80-V89 & Лицо, находившееся в автобусе и пострадавшее в результате транспортного несчастного \\
V90-V94 & случая \\
V95-V97 & Несчастные случаи, связанные с другими наземными транспортными средствами \\
V98-V99 & Несчастные случаи на водном транспорте \\
\hline
\end{tabular}

В практике российской государственной статистики данные о смертности разрабатываются хотя и с учетом Международной классификации, но по сокращенному списку номенклатуры, который периодически пересматривается. С переходом России на МКБ-10 в 1999 г. данные о дорожно-транспортной смертности перестали выделяться в отдельную причину. Связано это, прежде всего, с появлением более подробного списка выделяемых причин смерти и новой формулировкой автодорожного несчастного случая. Всемирная организация здравоохранения (BO3) разработала специальные рекомендации, какие транспортные причины смерти (в соответствии с новой кодировкой МКБ-10) необходимо относить к ДТП. В России, к сожалению, данная рекомендация не применяется. В 2005 и 2011 гг. Минздрав РФ пересматривал список номенклатуры причин смерти, действующий в России. С 2011 г. стали выделять 13 транспортных причин смерти (коды номенклатуры 256-268).

В зависимости от наличия статистических данных об умерших от транспортных происшествий в России условно можно выделить четыре периода по числу выделяемых причин смерти: 1956-1998, 1999-2005, 2006-2010 гг. и нынешний период - с 2011 г. (таблица 4). В таблице 6 приведено сопоставление кодов МКБ-10, рекомендованных ВОЗ для учета ДТП, и кодов, используемых для учета ДТП в России. 


\section{Таблица 4. Перечень причин смерти, выделяемых в транспортных происшествиях в соответствии с краткими номенклатурами, принятыми в СССР и России}

\begin{tabular}{|c|c|}
\hline Период & Перечень причин \\
\hline $1956-1998$ & $\begin{array}{ll}\text { - } & \text { несчастные случаи, связанные с мототранспортом } \\
\text { - } & \text { автомототранспортные несчастные случаи на общественной дороге в результате наезда на } \\
\text { пешехода } \\
\text { - } \quad \text { автомототранспортные несчастные случаи }\end{array}$ \\
\hline 1999-2005 & $\begin{array}{l}\text { • } \quad \text { пешеход, пострадавший в результате транспортного несчастного случая } \\
\text { - } \quad \text { лицо, находившееся в легковом автомобиле, пострадавшие в результате транспортного } \\
\text { несчастного случая } \\
\text { • } \quad \text { другие и неутонченные транспортные несчастные случаи }\end{array}$ \\
\hline $2006-2010$ & 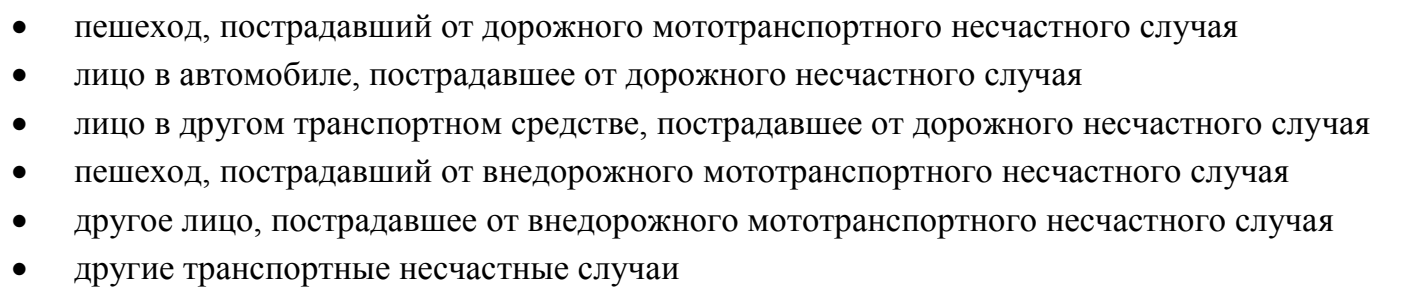 \\
\hline c 2011 & 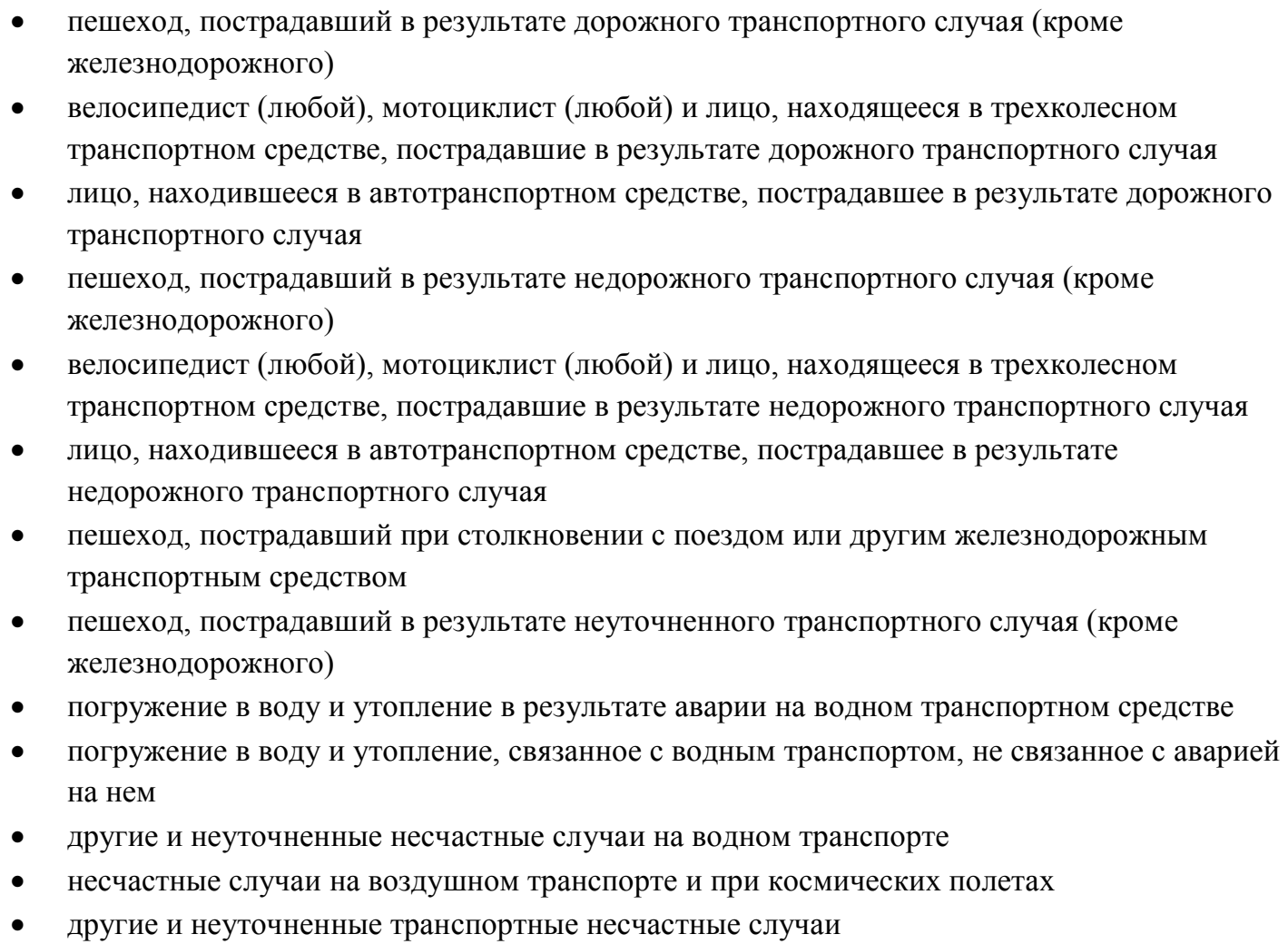 \\
\hline
\end{tabular}

Таблица 5. Коды МКБ-10, рекомендованные ВОЗ для определения ДТП, и коды, используемые для определения ДТП в России

\begin{tabular}{l|c}
\hline Рекомендация ВО3 & $\begin{array}{c}\text { Рекомендации к форме №57 "Сведения о травмах, отравлениях и } \\
\text { некоторых других последствиях воздействия внешних причин" }\end{array}$ \\
\hline V02-V04; V09; V12-V14; V20- & V01.1; V02.1; V03.1; V04.1; V09.1; V09.3; V83.2; V84.2; V85.2; V86.2; \\
V79; V82-V87; V89 & V10.3-9; V11.3-9; V12.3-9; V13.3-9; V14.3-9; V15.3-9; V16.3-9; V17.3-9; \\
& V18.3-9; V19.4-9; V20.3-9; V21.3-9; V22.3-9; V23.3-9; V24.3-9; V25.3-9; \\
& V26.3-9; V27.3-9; V28.3-9; V29.4-9; V30.4-9; V31.4-9; V32.4-9; V33.4-9; \\
& V34.4-9; V35.4-9; V36.4-9; V37.4-9; V38.4-9; V39.4-9; V40-V79.4-9 \\
\hline
\end{tabular}




\section{СМЕРТНОСТЬ ОТ ДТП В РОССИИ И ЕЕ МЕСТО В СТРУКТУРЕ ОБЩЕЙ СМЕРТНОСТИ И СМЕРТНОСТИ ОТ ВНЕШНИХ ПРИЧИН}

Как отмечалось, для России ряд чисел умерших от транспортных происшествий и ДТП, так же, как и от других причин смерти, имеется, начиная с 1956 г. С 1956 по 1998 г. сумма «несчастных случаев, связанных с мототранспортом» и «автомототранспортные несчастные случаи на общественной дороге в результате наезда на пешехода» давали общее число погибших в ДТП. В связи с неоднократным изменением номенклатуры причин смерти, данные за разные периоды не вполне сопоставимы, и для обеспечения сопоставимости российских показателей между собой и с показателями других стран понадобилась специальная работа по реконструкции сопоставимых временных рядов умерших по причинам смерти (включая ДТП). Самая известная реконструкция была опубликована в 1996 г. [Милле и др. 1996] и относится к периоду 1965-1994 гг. Несколько лет спустя тем же авторским коллективом, к которому присоединился Е.М. Андреев, ряд был продлен до 1956 г. [Meslé et al. 2003]. За 1995-1998 гг. имеются те же данные, рассчитанные Е.M. Андреевым на основе официальных статистических данных по смертности ${ }^{1}$.

Таблица 6. Источники информации о погибших в ДТП в России

\begin{tabular}{|c|c|c|c|}
\hline Источник информации & Тип данных & Ведомство & $\begin{array}{c}\text { Охватываемый } \\
\text { период }\end{array}$ \\
\hline [Росстат 1991-2013] & Открытые & ГИБДД & $1991-2013$ \\
\hline [Росстат 1980-2013] & Открытые & ГИБДД & $1980-2013$ \\
\hline [Росстат 2006-2013] & Открытые & Минздрав & 2006-2013 \\
\hline [Росстат 1997-2013] & Открытые & ГИБДД & $1997-2013$ \\
\hline [Росстат 1990-2013] & Открытые & ГИБДд & $1990-2013$ \\
\hline [Росстат 2000-2013] & Открытые & ГИБДд & $2000-2013$ \\
\hline [Росстат 1995-2013] & Открытые & ГИБДД & $1995-2009$ \\
\hline [WHO Mortality Database] & Открытые & Минздрав & 1980-1998 \\
\hline [Базы данных ООН] & Открытые & ГИБДд & $1993-2012$ \\
\hline $\begin{array}{l}\text { Неперсонифицированные данные } \\
\text { (непубликуемые данные } \\
\text { Росстата) }\end{array}$ & Закрытые & Минздрав & $1999-2014$ \\
\hline $\begin{array}{l}\text { Форма медицинской отчетности } \\
\text { №40 «Отчет станции (отделения), } \\
\text { больницы скорой помощи» } \\
\text { (непубликуемые данные } \\
\text { Минздрава) }\end{array}$ & Закрытые & Минздрав & $1999-2014$ \\
\hline [Милле и др. 1996] & Открытые & $\begin{array}{c}\text { Исследование на данных } \\
\text { Росстата }\end{array}$ & $1956-1964$ \\
\hline [Meslé et al. 2003] & Открытые & $\begin{array}{c}\text { Исследование на данных } \\
\text { Росстата }\end{array}$ & $1965-1994$ \\
\hline Е.М. Андреев* & Открытые & $\begin{array}{c}\text { Исследование на данных } \\
\text { Росстата }\end{array}$ & 1995-1998 \\
\hline
\end{tabular}

Примечание: * - Данные можно найти на сайте Демоскоп Weekly. URL:

http://demoscope.ru/weekly/app/appbd01.php (дата обращения 11.09.2015).

\footnotetext{
${ }^{1}$ Данные доступны в Российской базе данных по рождаемости и смертности (РосБРиС) Центра демографических исследований Российской экономической школы (ЦДИ РЭШ). http://www.demogr.nes.ru/index.php/ru/demogr_indicat/data_description.
} 
Данные о ДТП и их последствиях в России публикуются в разных статистических сборниках, также их можно найти в международных базах данных и некоторых исследованиях (таблица 6).

На сегодняшний день основным первичным источником информации о ДТП в большинстве развитых стран (90\%) [Derriks, Mak 2007] и в России, в частности, являются протоколы полиции. Медицинская отчетность используется как вспомогательный источник информации.

Практически во всех странах существуют расхождения между данными органов здравоохранения и дорожной полиции. Но расхождения обычно невелики и в редких случаях превышают 6-7\% (рисунок 4).

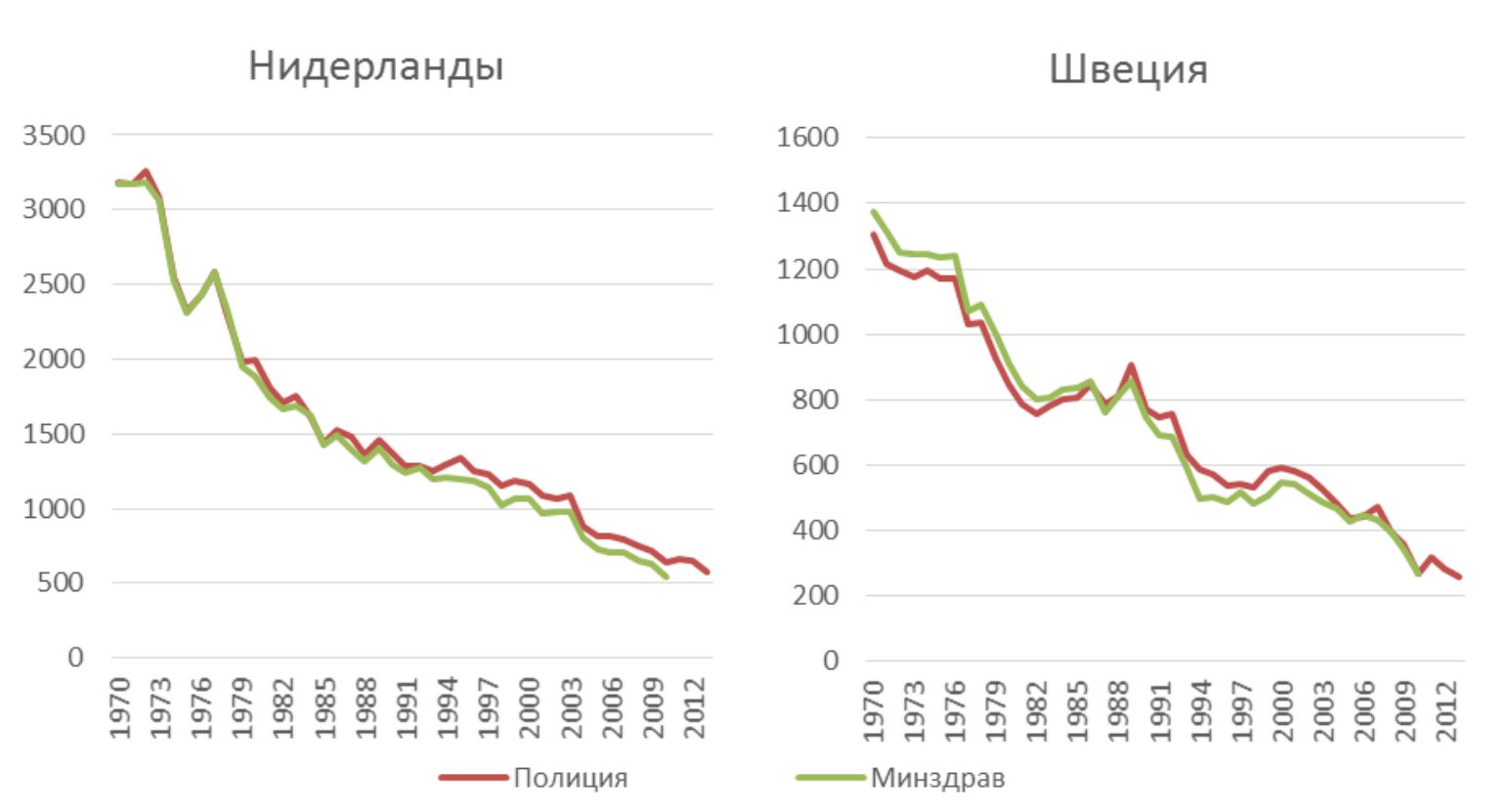

Рисунок 4. Расхождения межведомственных данных в Швеции и Нидерландах, 1970-2013

Источники: [OECD...; WHO Mortality Database].

Российская специфика заключается в масштабе межведомственных расхождений (25-30\%), который нехарактерен для других стран. Недоучет погибших в ДТП, который допускает Минздрав, хорошо виден при сопоставлении данных о погибших из российского демографического ежегодника [Росстат 2006-2013] и данных ГИБДД [ГИБДД...] (рисунок $5)$. 


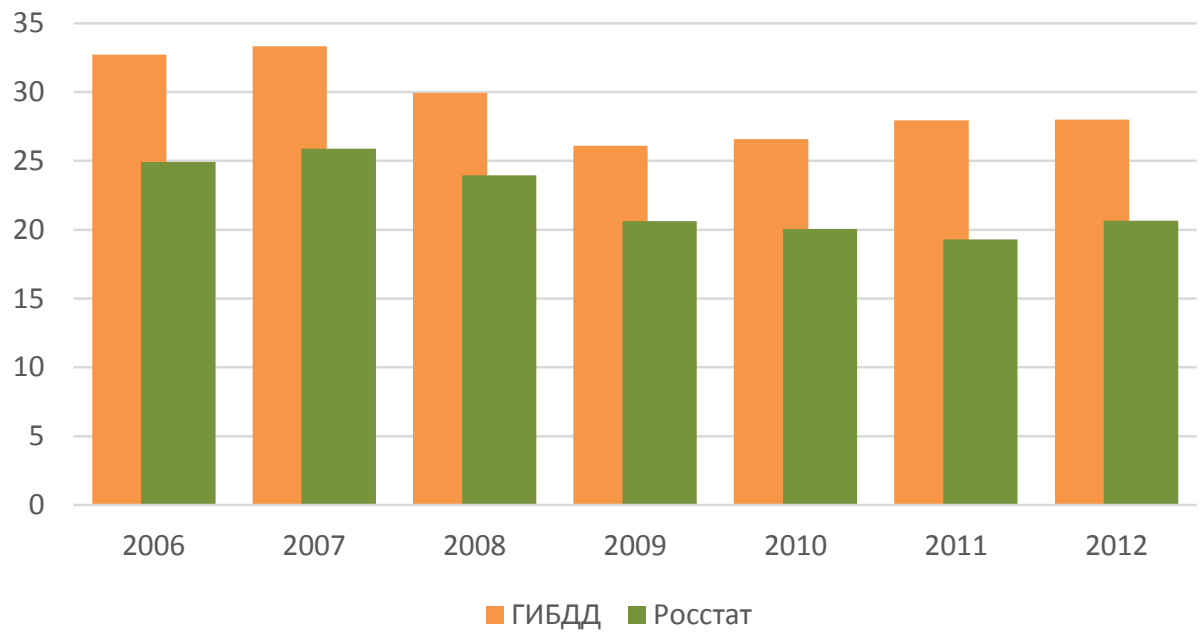

Рисунок 5. Погибшие в ДТП по данным Росстата и ГИБДД, тыс.

Источники: [ГИБДД ...; Росстат 2006-2013].

Реконструкция чисел погибших от ДТП с 1956 по 2014 г. из всех имеющихся источников информации представлена на рисунке 6. Из рисунка 6 видно, что до 1998 г. данные Минздрава и ГИБДД совпадали. С 1999 по 2005 г. данные Минздрава о погибших в ДТП не публиковались (в этот период публикуются только данные ГИБДД), они появляются лишь в 2006 г. в демографическом ежегоднике [Росстат 2006-2013]. Именно с 2006 г. появляется разрыв в межведомственных данных, который до сих пор не устранен. На рисунке 6 также видно, что бы мы получили, если бы с 1999 г. воспользовались рекомендацией ВОЗ для определения ДТП по МКБ-10. В этом случае межведомственные расхождения в данных о погибших в ДТП сводились бы к минимуму (линия неперсонифицированных данных).

Несмотря на расхождения в данных, тренд дорожно-транспортной смертности хорошо виден. С 1956 по 1980 г. число смертей от ДТП устойчиво росло, затем оно снизилось на короткое время в период антиалкогольной кампании и «перестройки», после чего снова возобновило рост, достигнув исторического максимума в 1991 г. Затем последовало снижение, сменившееся после 1998 г. новым подъемом, достигшим пика в 2003 г. Этот подъем оказался временным, после 2003 г. возобновилось снижение, идущее с небольшими колебаниями до сих пор. 


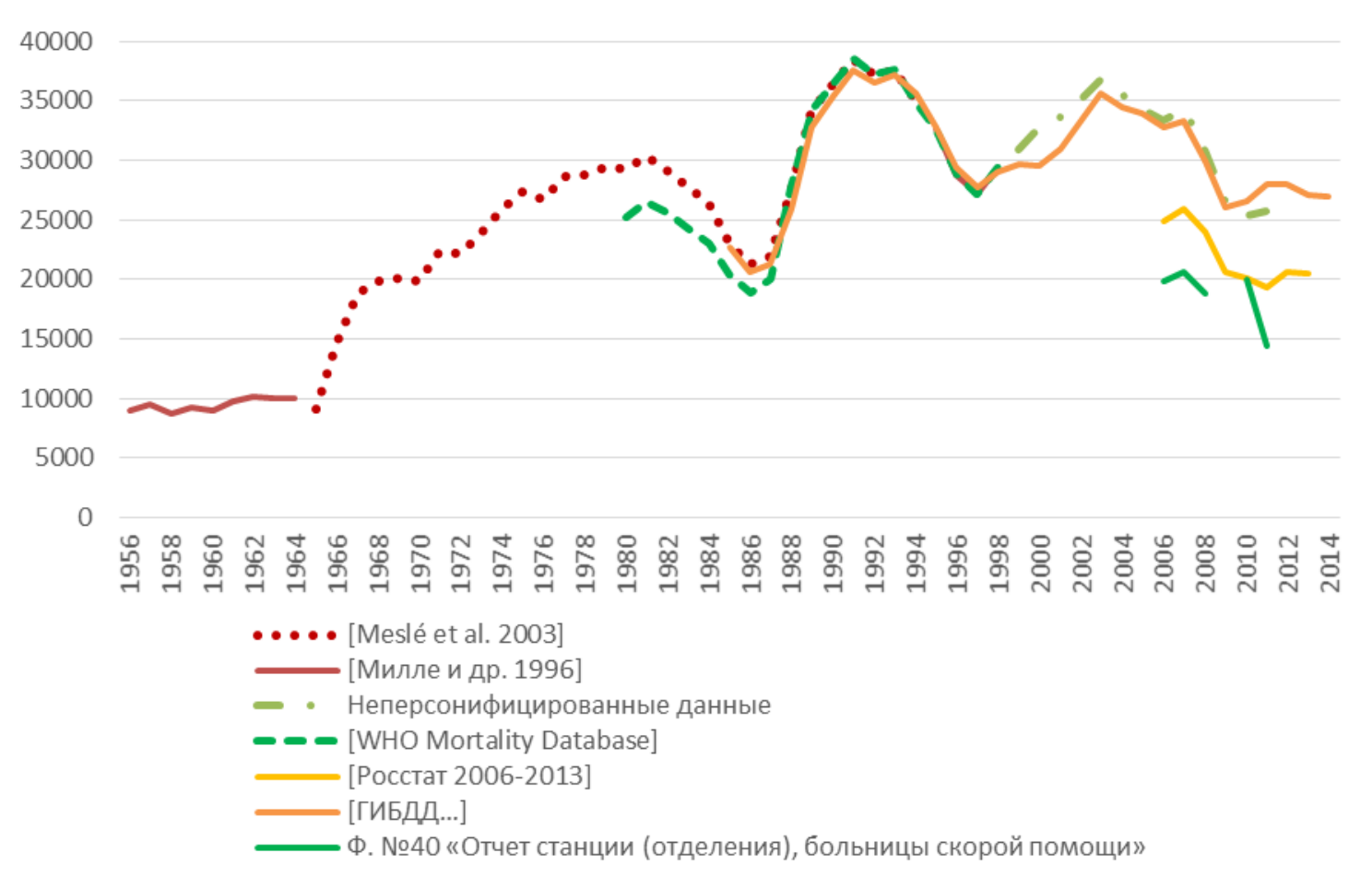

Рисунок 6. Реконструкция чисел погибших от ДТП в России, 1956-2014 гг.

По динамике смертности от ДТП Россия заметно отличается от развитых стран. При очень высоком уровне российской смертности от ДТП в последние четверть века ее динамика была крайне неустойчивой. Согласно данным ВОЗ смертность от ДТП в развитых странах до начала 70-х годов XX века росла, но затем наступил перелом, и с тех пор она непрерывно снижается. Для этих стран нехарактерны взлеты и падения дорожнотранспортной смертности, наблюдаемые в России, они лишь увеличивают отставание России.

В 2000-е годы число погибших от ДТП в России снова стало снижаться, но снижение было меньшим, чем в других странах. При этом число самих ДТП и число раненых в России росло, тогда как в большинстве других стран падало [Вишневский, Фаттахов 2012]. Россия, даже с учетом нисходящей ветви колебания последних лет, по величине стандартизованного коэффициента смертности от ДТП находится на уровне, который был пройден развитыми странами еще в 1980-е годы [Фаттахов 2014]. Соответственно, отставание России от других стран остается существенным. Например, в 2010 г. измеряемый по стандартизованному коэффициенту смертности разрыв с такими странами, как Швеция, Нидерланды или Великобритания, был шестикратным. При этом колебательное движение уровня смертности от ДТП, которое наблюдается в России на протяжении последних четырех десятилетий, постоянно заставляет опасаться, что наблюдаемое снижение смертности может быть прервано очередным ее подъемом (рисунок 7). 


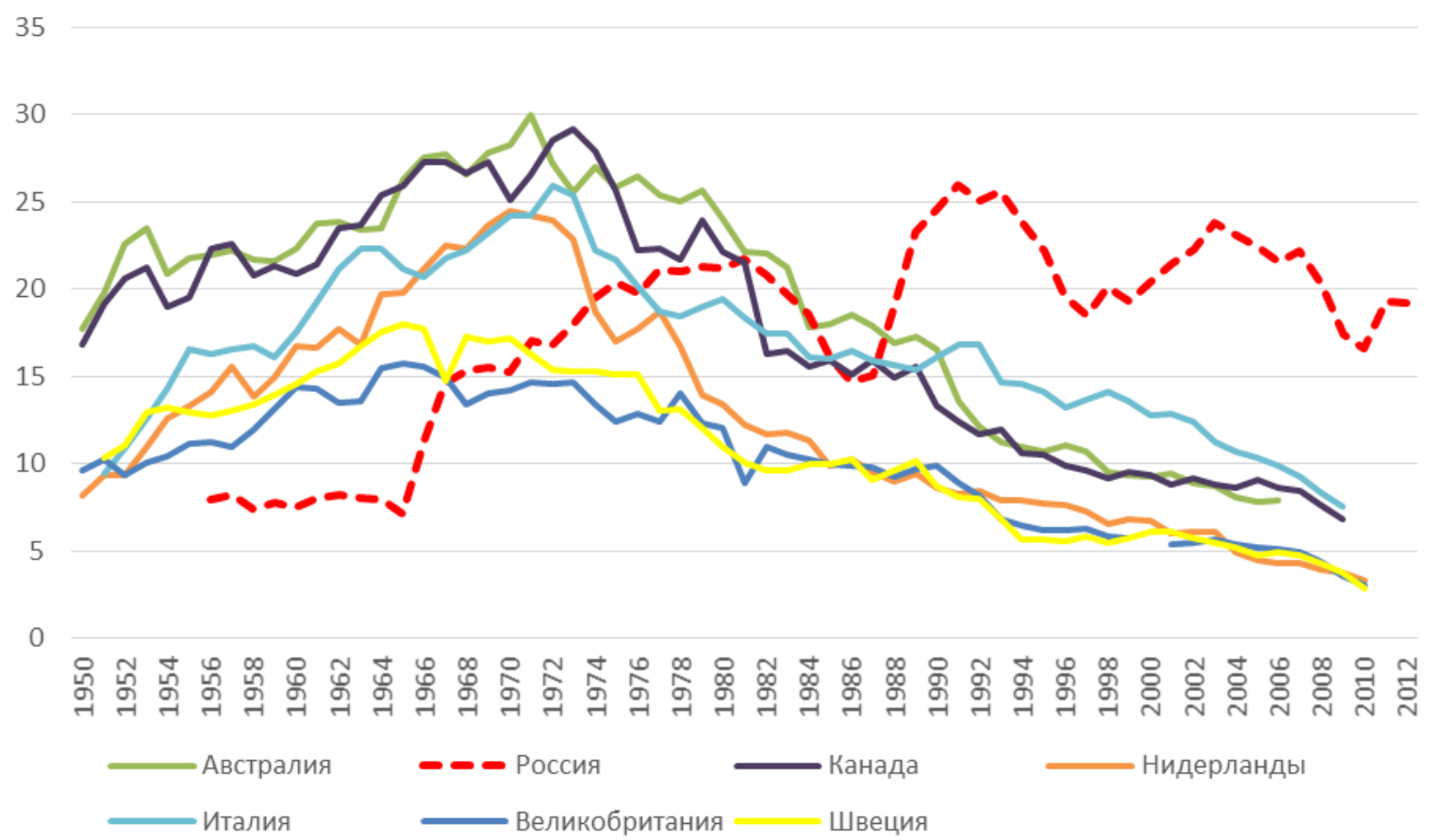

\section{Рисунок 7. Стандартизованный коэффициент смертности от ДТП в России и некоторых развитых странах, 1950-2012, на 100 тыс.}

Источник: расчеты автора на основе [WHO Mortality Database] и реконструированных данных о смертности от ДТП.

ДТП и их последствия - неизбежный спутник автомобилизации - представляют собой серьезную социально-гигиеническую проблему во всем мире. Но в России, если сравнивать ее со странами сходного уровня развития, эта проблема стоит особенно остро. В целом ряде стратегических и программных документов вопросы обеспечения безопасности дорожного движения определены в качестве приоритетов социальноэкономического развития России. Внедрение программ повышения безопасности на дорогах Президент России В. Путин назвал одной из актуальных задач развития страны [Общественный доклад... 2014]. Такой интерес к проблеме неслучаен. Размер социальноэкономического ущерба от ДТП и их последствий за 2004-2011 гг. оценивается более чем в 8 триллионов рублей, что сопоставимо с доходами консолидированных бюджетов субъектов России за 2012 г. [О федеральной целевой программе... 2014].

По данным Росстата, в России с 1956 по 2012 г. в ДТП погибло 1411 тыс. человек. По сведениям ГИБДД, с 1985 по 2012 г. общее число ДТП с пострадавшими составило свыше 5 млн, в них, помимо 856,4 тыс. погибших, более 6 млн человек получили ранения различной степени тяжести. Лишь около $40 \%$ этих травм относятся к легким поверхностным, остальные 60\% можно классифицировать как тяжелые (открытые раны, сотрясения, переломы, травмы внутренних органов, ожоги и т.д.) [Форма №57... 2011]. По причине ДТП 6 тыс. человек ежегодно становятся инвалидами 1-й, 2-й и 3-й групп [Форма №7... 2012]. По данным Министерства здравоохранения, в России общая смертность пострадавших в ДТП в 12 раз выше, чем при получении травм в результате других происшествий, инвалидность в 6 раз выше, а потребность в госпитализации в 7 раз чаще [О федеральной...]. 
Если бы население России умирало от ДТП так же, как, например, население Швеции (в расчете на 100 тыс. населения), то в 2012 г. в России погибло бы не 27991 человек, а всего 3627, или на 24364 человека меньше (таблица 7). Если распространить это избыточное число смертей на весь период с 1990 по 2012 г., и оценить совокупные потери населения за 22 года, то они составили бы не 744 тыс. человек, а всего 194 тыс., а избыточная смертность в этом случае достигает 550 тыс. человек или 25 тыс. человек в год.

Избыточные потери можно оценить и другими способами. Так, если сопоставлять число погибших не на 100 тыс. населения, а на километр автомобильных дорог, то получится, что в России от ДТП (по сравнению со Швецией) в 2012 г. умерло бы не 28 тыс. человек, а всего 1146 (таблица 7).

Если же делать оценки с учетом плотности автопарка и сопоставить показатели транспортных рисков (число погибших на 10 тыс. автомобилей), то если бы в России в 2012 г. этот показатель был бы таким же, как в Швеции, то смертность от ДТП составила бы 1683 человека (таблица 7), а суммарные избыточные смерти с 1990 по 2012 г. составили бы 696 тыс. человек. В таблице 7 представлены такие сопоставления с тремя странами Великобританией, Нидерландами и Швецией.

Таблица 7. Гипотетическое число погибших от ДТП в России в 2012 г. при уровне смертности, достигнутом в трех развитых странах, и избыточное число погибших вследствие более высокой смертности в России

\begin{tabular}{|c|c|c|c|c|c|c|}
\hline \multirow[b]{2}{*}{ Показатели } & \multicolumn{3}{|c|}{$\begin{array}{c}\text { Гипотетическое число } \\
\text { погибших при смертности: }\end{array}$} & \multicolumn{3}{|c|}{$\begin{array}{l}\text { Избыточное число погибших в России по } \\
\text { сравнению с возможным при смертности: }\end{array}$} \\
\hline & 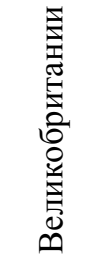 & 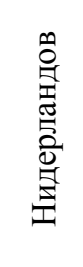 & 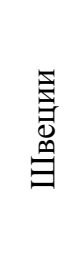 & 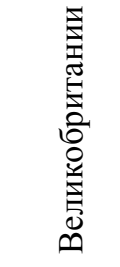 & 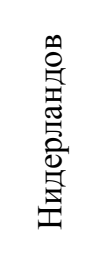 & $\begin{array}{l}\stackrel{\Xi}{\Xi} \\
\text { 总 } \\
\text { 香 }\end{array}$ \\
\hline $\begin{array}{l}\text { Погибшие на } 100 \text { тыс. } \\
\text { населения }\end{array}$ & 3945 & 4088 & 3627 & 24046 & 23903 & 24364 \\
\hline $\begin{array}{l}\text { Погибшие на } 10 \text { тыс. } \\
\text { транспортных средств }\end{array}$ & 1930 & 1965 & 1683 & 26061 & 26026 & 26308 \\
\hline $\begin{array}{l}\text { Погибшие на } 1000 \text { км } \\
\text { автодорог }\end{array}$ & 4451 & 4199 & 1146 & 23540 & 23792 & 26845 \\
\hline
\end{tabular}

Как следует из таблицы 7, разные способы оценки избыточной российской смертности при сравнении России с несколькими странами дают не совсем одинаковые результаты, но различия не принципиальные. При фактическом числе погибших от ДТП в России в 2012 г. около 28 тыс. от 23,5 тыс. до 26,8 тыс. (84-96\%) были избыточными, при смертности от ДТП, характерной для западноевропейских стран, их могло бы не быть.

Разумеется, подобное сопоставление имеет достаточно условный характер, в настоящее время достижение подобных результатов в России едва ли возможно. Тем не менее оно указывают на огромные неиспользованные резервы снижения смертности от ДТП и свидетельствует о принципиальной возможности такого снижения. 
В структуре общей смертности в России на ДТП приходится около 1,5\% всех смертей. Доля смертей от ДТП в общей структуре внешних причин колеблется, иногда достигая довольно высоких значений, как это было, например, в конце 1980-х - начале 1990-х годов (18\%), но в целом это колебания в диапазоне $10-14 \%$ (рисунок 8).

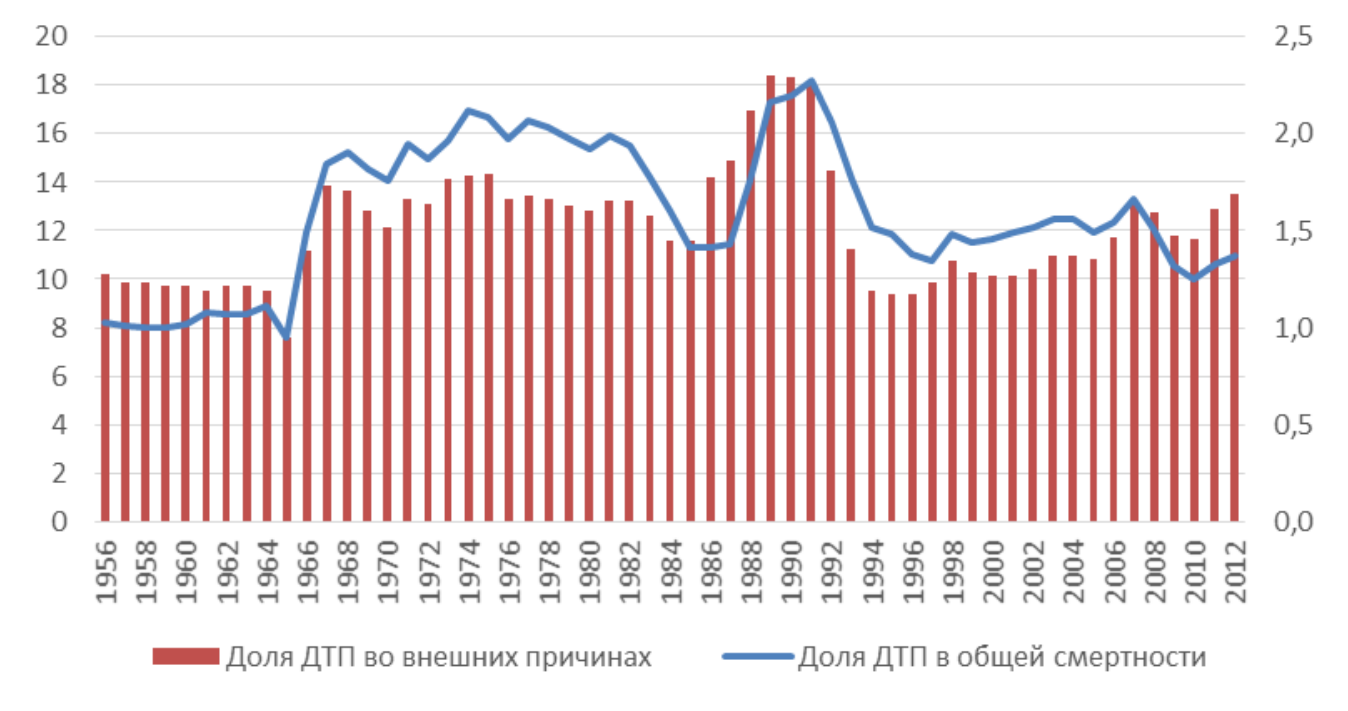

Рисунок 8. Доля умерших от ДТП в общем числе умерших (ось справа) и в числе умерших от внешних причин смерти (ось слева) в 1956-2012 гг., \%

Источник: Расчеты автора на основе реконструированных данных о смертности от ДТП.

Хотя смертность от ДТП вносит большой вклад в смертность россиян от всех внешних причин, в структуре смертности от этих причин ДТП принадлежит все же не первое место. На протяжении второй половины XX века с ней конкурировали, конкурируют и сейчас такие причины, как самоубийства, убийства, случайные отравления. В последние годы возросло значение повреждений с неопределенными намерениями [Васин, Кренев 2012]. В целом динамика всех основных причин данного класса схожа (рисунок 9).

В 2012 г. на долю ДТП во внешних причинах смерти приходилось 14,4\%, больше людей погибало от самоубийств, повреждений с неопределенными намерениями и случайных отравлений алкоголем (рисунок 10). 


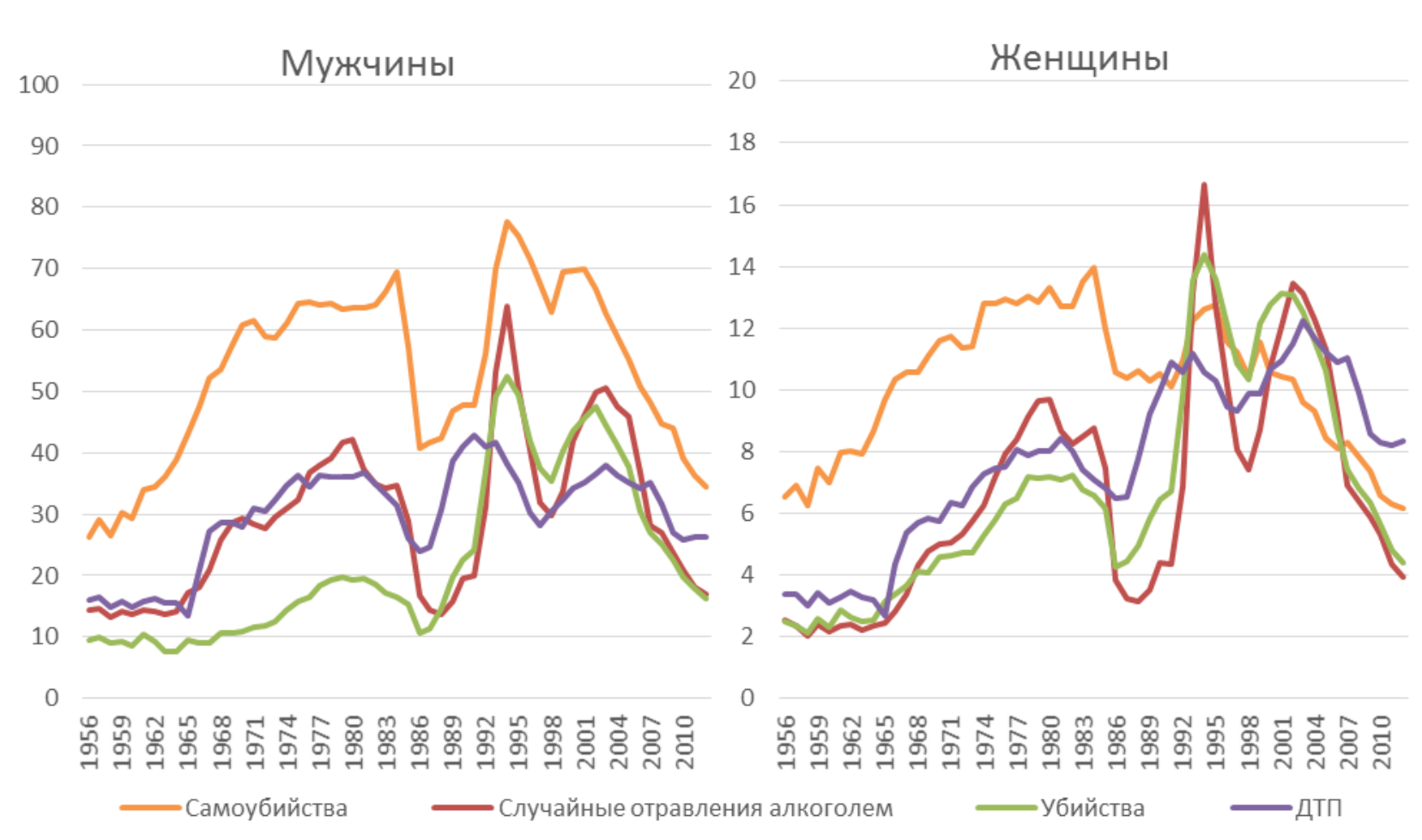

\section{Рисунок 9. Стандартизованный коэффициент смертности от некоторых внешних причин смерти в России, 1956-2012 гг.}

Источник: Расчеты автора на основе неопубликованных данных Росстата.

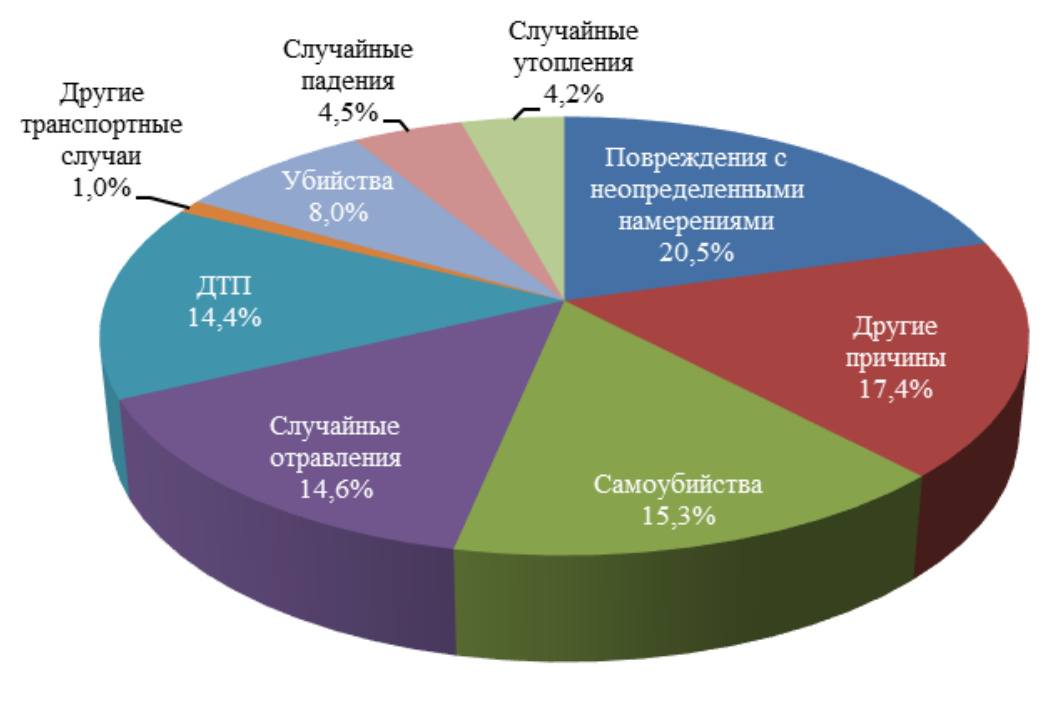

\section{Рисунок 10. Распределение абсолютного числа смертей от внешних причин по видам причин в 2012 г., \%}

Источник: [Росстат 2006-2013].

Доля смертей от ДТП во внешних причинах смерти различается по странам. Так, в Греции дорожно-транспортная смертность составляет почти 40\% от всех внешних причин. Наименьшие показатели наблюдаются в скандинавских странах и Японии (рисунок 11). На графике Россия занимает срединное положение, но надо учитывать, что общий уровень 
смертности от внешних причин в России, как правило, намного выше, чем в приведенных странах.

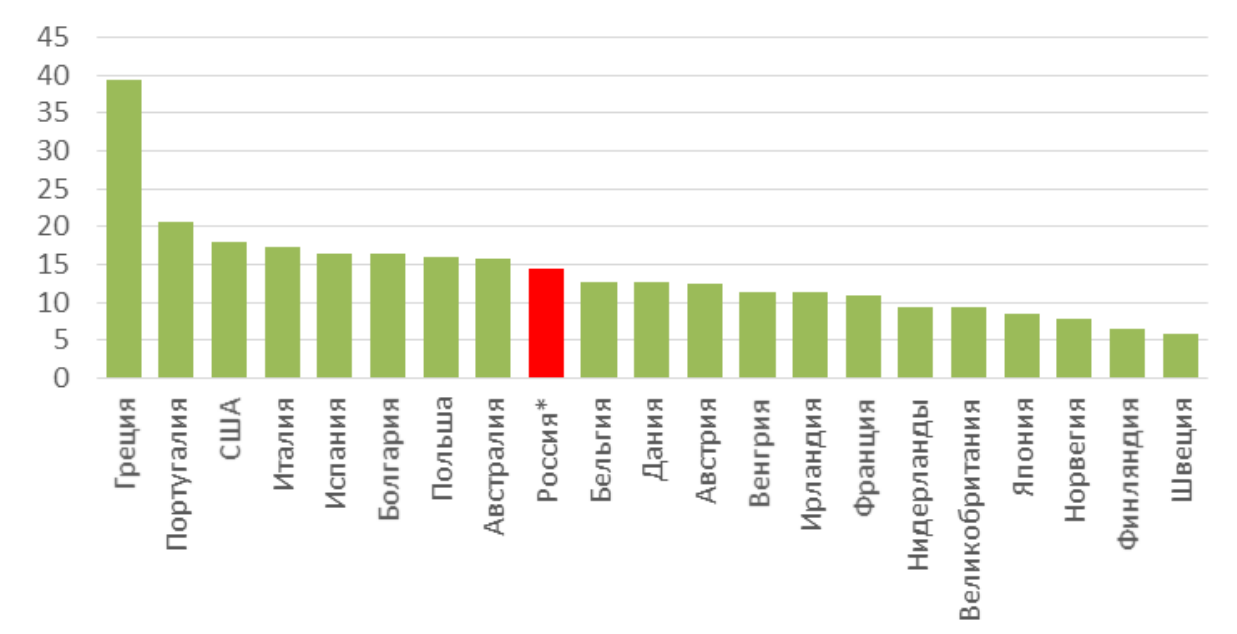

Рисунок 11. Доля смертей от ДТП в общем числе смертей от внешних причин в некоторых странах в 2010 г., \%

Примечание: * - по данным [ГИБДД...].

Источник: [WHO Mortality Database].

В структуре транспортной смертности ДТП везде занимают лидирующее место. На них приходится от 80 до 90\% смертей от всех транспортных несчастных случаев, и по этому показателю Россия также не выделяется на фоне других стран (рисунок 12).

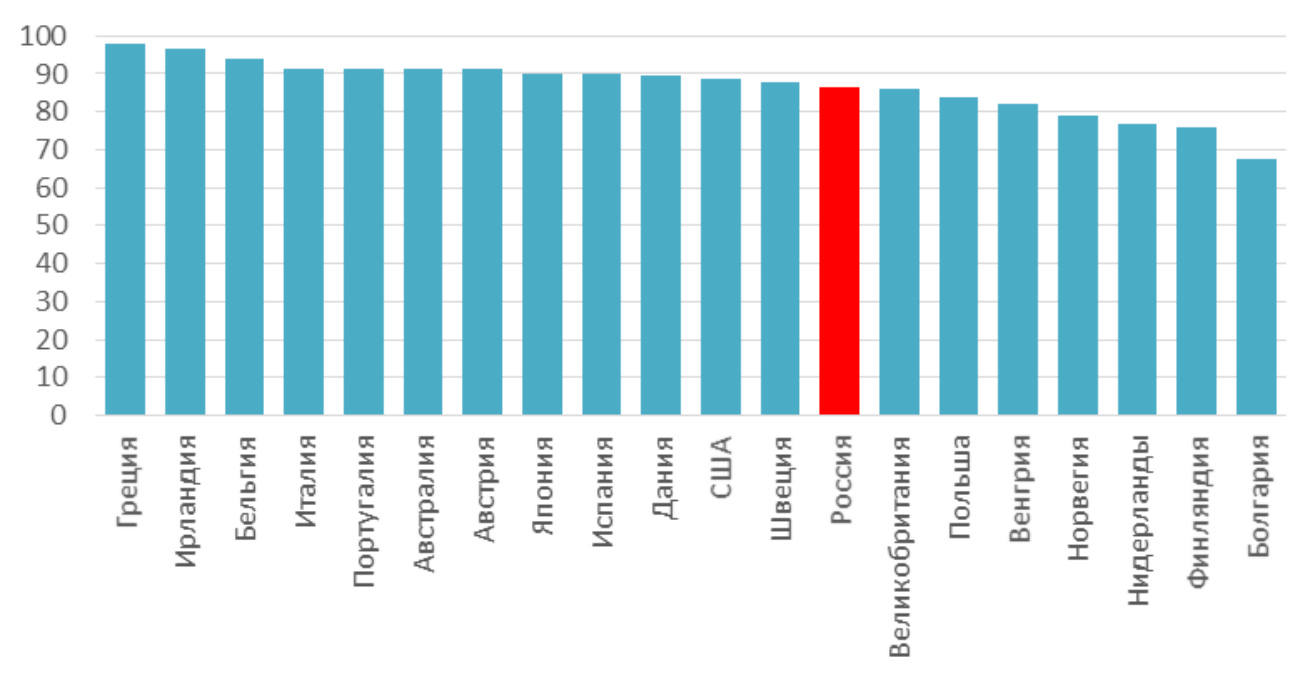

Рисунок 12. Доля смертей от ДТП в смертности от транспортных несчастных случаев в некоторых странах в 2010 г., \%

Источник: [WHO Mortality Database]. 


\section{ПОЛОВОЗРАСТНЫЕ ОСОБЕННОСТИ РОССИЙСКОЙ СМЕРТНОСТИ ОТ ДТП}

Смертность от ДТП в России демонстрирует как общие для всех стран различия, так и специфические особенности.

Используя стандартизованный коэффициент смертности от ДТП, можно сравнить смертность российских и западноевропейских мужчин и женщин. В России в начале $1970-$ $\mathrm{x}$ годов этот коэффициент был ниже, чем в странах Западной Европы. Снижение смертности от ДТП в странах Западной Европы и одновременно ее рост в России резко увеличили разрыв не в пользу России. В начале 1980-х годов смертность от ДТП в России и у мужчин, и у женщин начала снижаться и к середине 1980-х достигла среднеевропейского уровня, затем еще более резко взлетела, в то время как в Европе стандартизованный коэффициент смертности от ДТП устойчиво снижался. В последнее десятилетие наметилось некоторое сближение показателей, но по сути, речь идет лишь о возврате к уровню середины 1990-х годов, отставание от стран Западной Европы сохраняется (рисунок 13).

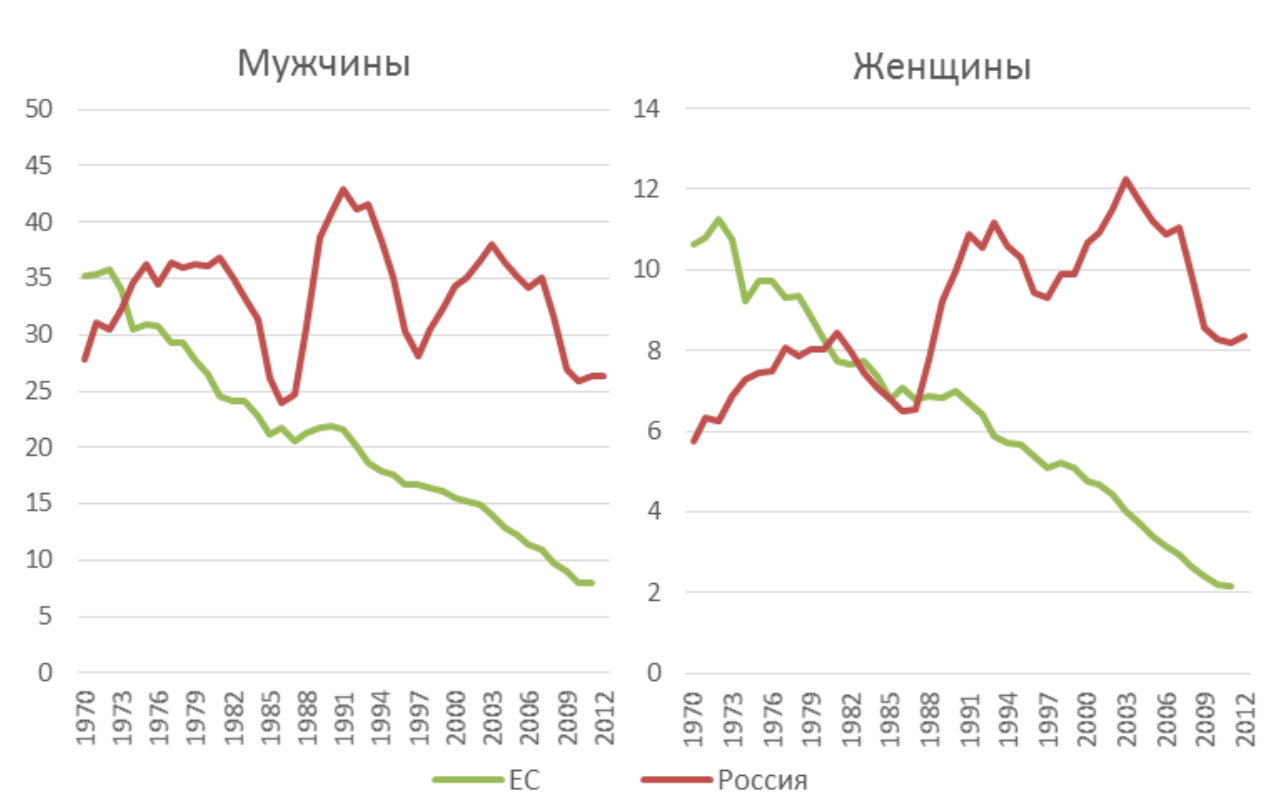

\section{Рисунок 13. Стандартизованный коэффициент смертности мужчин и женщин от ДТП в России и 15 странах - членах Европейского Союза до мая 2004 года, 1970-2012 гг.}

Источники: [WHO Mortality Database], реконструированные данные о смертности от ДТП.

Во всех странах и по всем возрастным группам вместе взятым смертность от ДТП среди мужчин в 2,5-3 раза выше, чем среди женщин. Как и можно было ожидать, это различие не обнаруживается в возрастной группе до 1 года, но уже в группе 1-4 года показатели смертности для представителей мужского пола выше. В возрастной группе 5-14 лет отношение показателей для мальчиков и девочек находится в интервале между 1,5-2:1, в группе 15-29 лет и 30-44 года соотношение для мужчин и женщин составляет 3-5:1; в возрастах 45-59 лет оно снижается до 3,5:1 и еще больше снижается для возрастной категории 65 лет и более. Весьма примечательно постоянство соотношения показателей по 
признаку пола для всех стран в возрастных категориях 1-4 года, 5-14 и свыше 65 лет (рисунок 14).
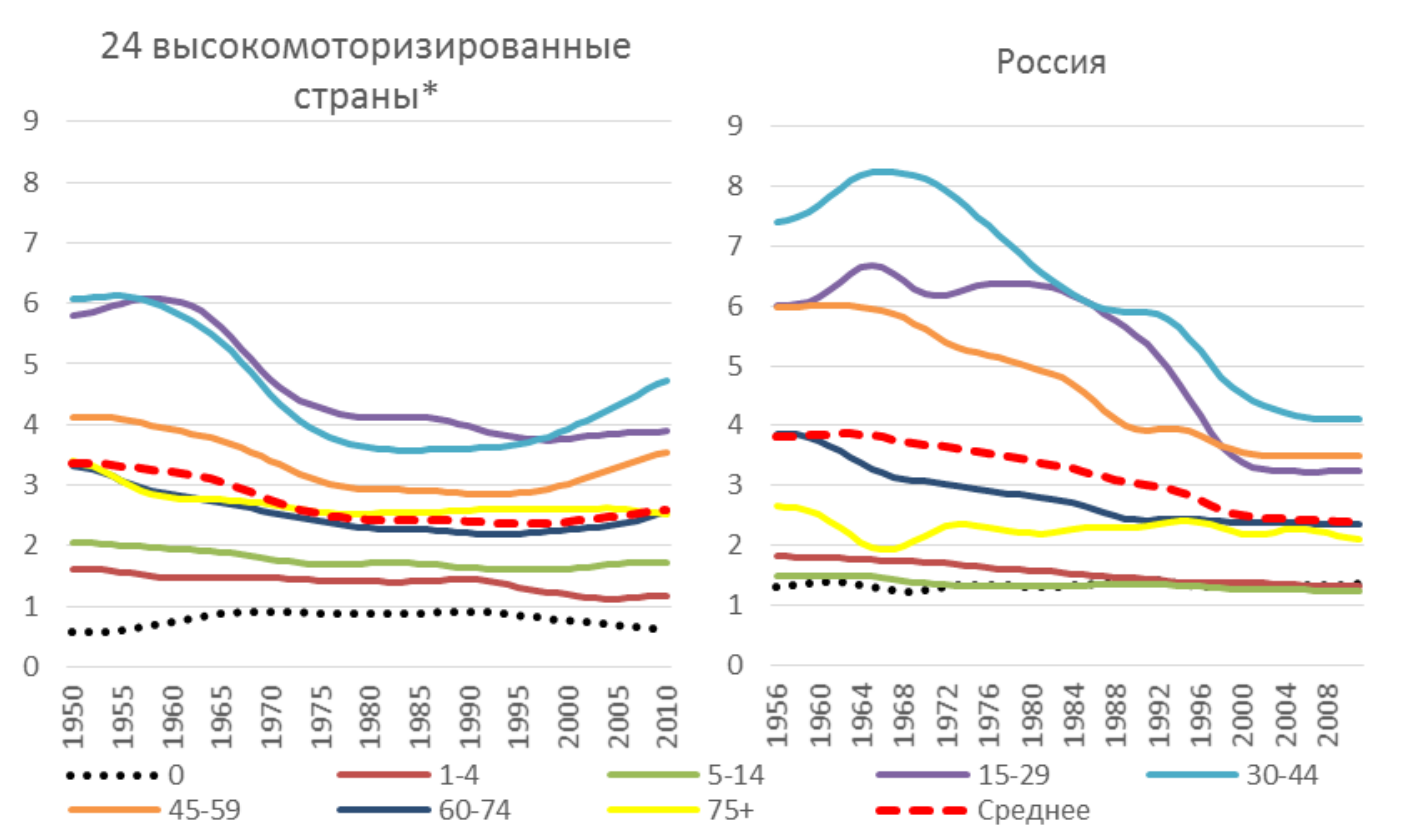

\section{Рисунок 14. Соотношение полов среди погибших от ДТП в разных возрастных группах в 1950-2011 гг., мужчин на 1 женщину}

* Австралия, Австрия, Бельгия, Болгария, Канада, Дания, Финляндия, Франция, Греция, Венгрия, Исландия, Ирландия, Италия, Япония, Нидерланды, Новая Зеландия, Норвегия, Польша, Португалия, Россия, Испания, Швеция, Великобритания, США.

Источники: [WHO Mortality Database], реконструированные данные о смертности от ДТП.

В России возрастной профиль смертности, начиная с 60-х годов, непрерывно изменялся и постепенно принимал форму кривой с ярко выраженным молодежным «горбом» смертности. Изменения смертности от ДТП показывают резкое повышение смертности в возрастных группах 15-24 года и 75 и более лет. Максимальные значения этих показателей ясно выражены у мужчин и значительно менее - у женщин, особенно в возрастной группе 15-24 года. К началу 1990-х годов возрастной профиль мужской смертности от ДТП в России достиг максимальных значений, у женщин максимальные значения были достигнуты в 2000-е годы (рисунок 15).

Такой возрастной профиль смертности от ДТП характерен не только для России, но и для большинства стран. Смертность вследствие ДТП как бы следует какой-то биологической или социологической закономерности, действующей в равной степени во всех странах. В большинстве из них и у мужчин, и у женщин первый пик дорожнотранспортной смертности наблюдается в возрасте 20-24 года, второй - в возрасте 85 и более лет. Но в России показатели смертности во всех возрастах выше, чем в других странах. Особенно это выражено в детских и трудоспособных возрастах (рисунок 16). 

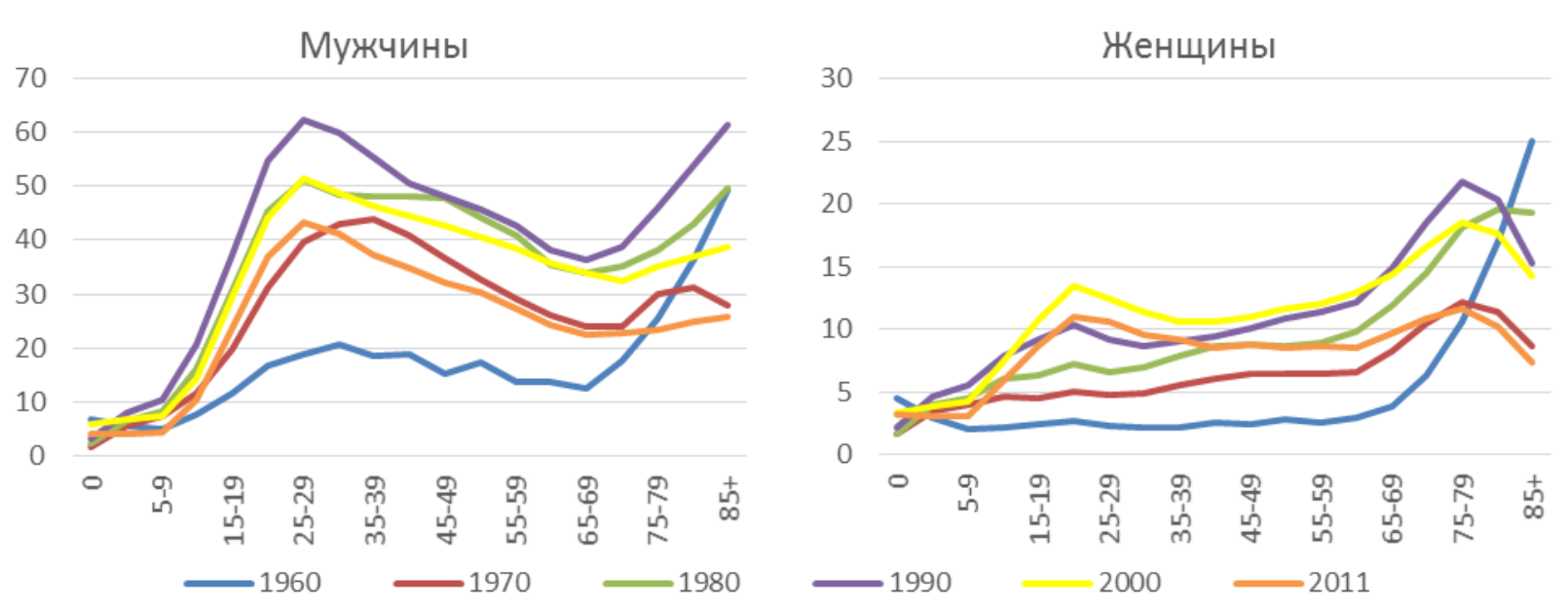

Рисунок 15. Возрастные коэффициенты смертности от ДТП в России, на 100 тыс. населения соответствующего пола и возраста

Источник: реконструированные данные о смертности от ДТП.

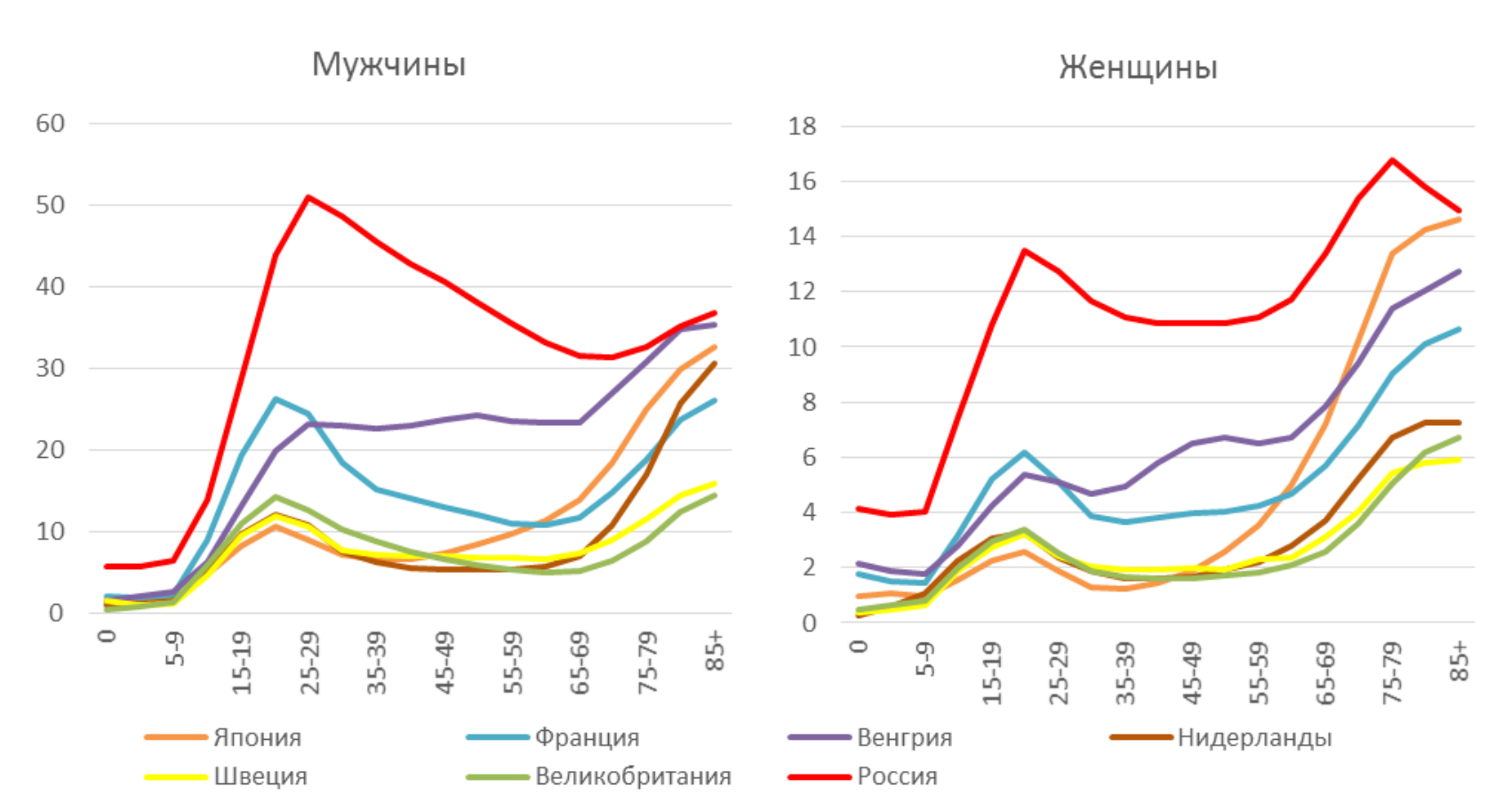

Рисунок 16. Возрастные коэффициенты смертности от ДТП в России и некоторых странах мира. Средние значения за 2000-2011 гг., на 100 тыс. населения соответствующего пола и возраста

Источники: [WНО Mortality Database], реконструированные данные о смертности от ДТП.

В России динамику возрастных коэффициентов смертности от ДТП можно проследить с 1956 г. Тенденции этой динамики во всех возрастных группах, кроме самой младшей, в основном совпадают, при этом самые высокие уровни у мужчин устойчиво держатся в возрастах от 15 до 45 лет, у женщин при гораздо меньших уровнях, чем у мужчин, существенно выделяется группа пожилых в возрасте 75 лет и старше (рисунок 17). 


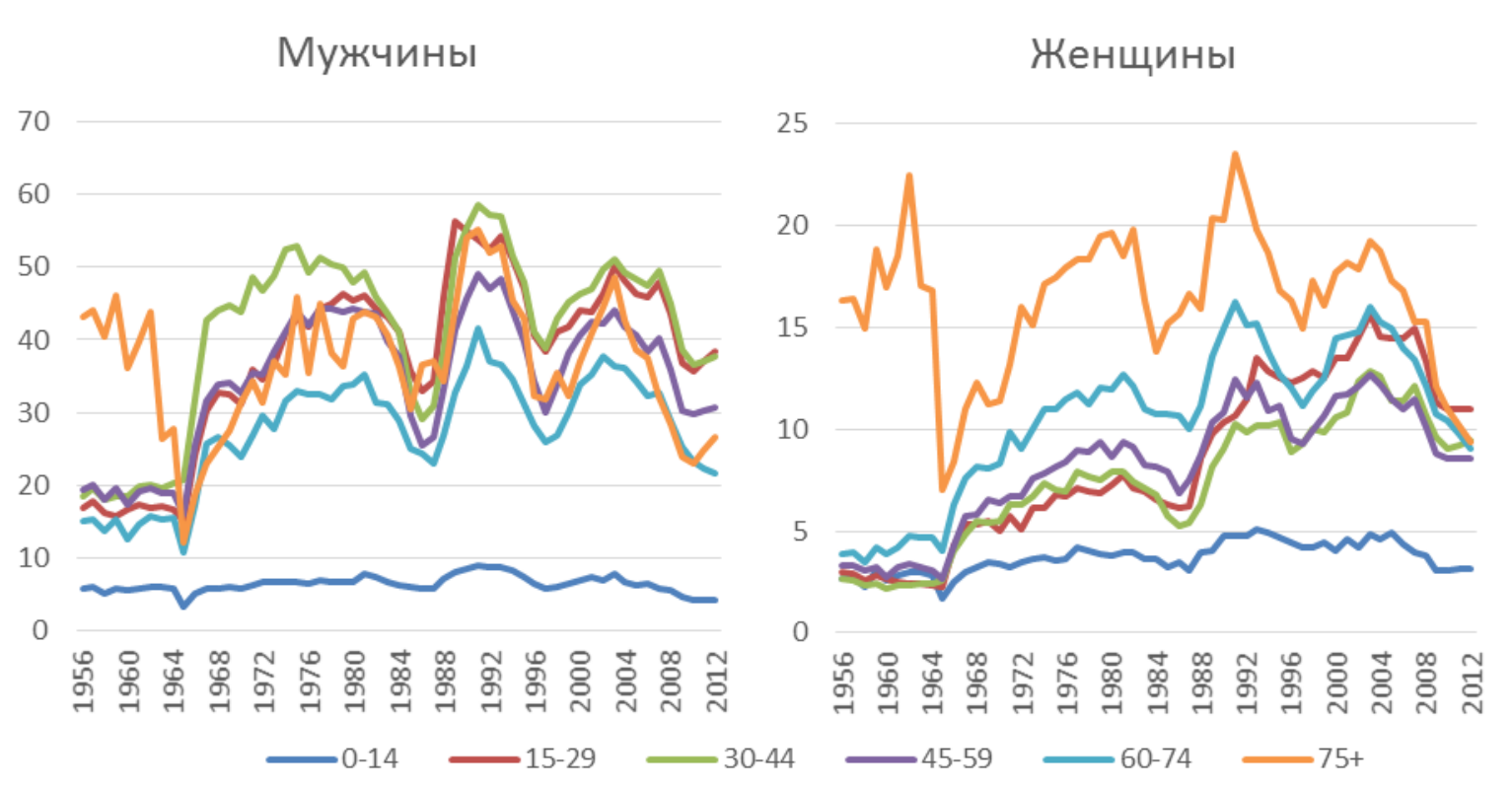

Рисунок 17. Возрастные коэффициенты смертности от ДТП в России в 1956-2012 гг., пятнадцатилетние возрастные группы, на 100 тыс. соответствующего населения

Источник: реконструированные данные о смертности от ДТП.

\section{ВОДИТЕЛИ, ПАССАЖИРЫ И ПЕШЕХОДЫ}

В России информацию о погибших в результате ДТП по категориям участников дорожного движения можно проследить с 1991 г. По данным ГИБДД, до 2009 г. главной группой риска на российских дорогах были пешеходы. В первой половине 1990-х годов снижение смертности от ДТП было характерно для всех групп участников дорожного движения. С 1998 по 2003 г. общая смертность от ДТП росла, но особенно сильно - за счет уязвимых участников дорожного движения. С 2004 г. смертность пешеходов вновь стала снижаться, чего нельзя сказать о смертности водителей и пассажиров транспортных средств. Общий тренд снижения дорожно-транспортной смертности, наблюдаемый в последнее десятилетие, полностью определялся тенденциями смертности пешеходов (рисунок 18).

Снижение смертности пешеходов в последнее время, безусловно, большой прогресс для России, но отставание от передовых стран остается существенным. В 1991 г. в России на каждые 100 тыс. населения погибало 9 пешеходов, в европейских странах - лишь 2,8. В 2013 г. на дорогах России погибало уже 6 человек на каждые 100 тыс. населения, а в европейских странах - 0,9. В обоих случаях показатель снизился, но разрыв между Россией и европейскими странами за это время увеличился и стал не трехкратным, а шестикратным. 


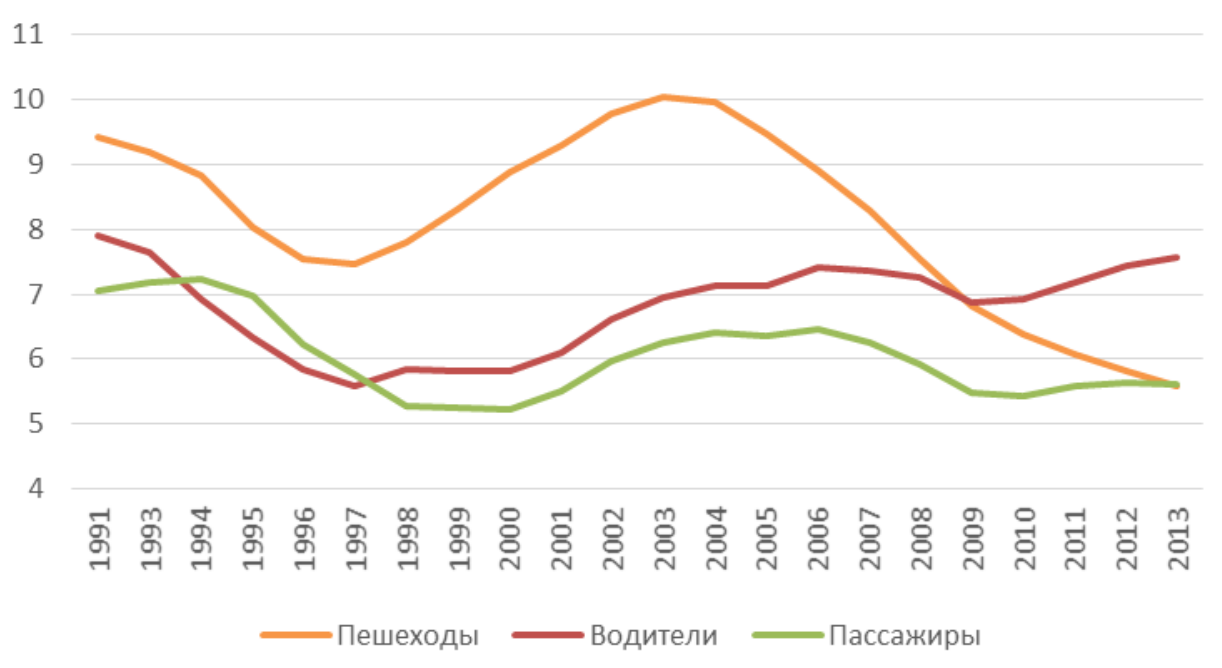

\section{Рисунок 18. Общий коэффициент смертности от ДТП разных участников дорожного движения в России в 1991-2013 гг., на 100 тыс. населения}

Источник: Расчеты автора на основе данных [ГИБДД...].

Смертность российских водителей и пассажиров с 1998 г. не снижается, а отставание России от европейских стран по этому показателю нарастает. В 1991 г. на каждые 100 тыс. населения в России погибало 15,5 водителей и пассажиров, в европейских странах - всего 8. Разрыв был двукратным. В 2013 г. в России на каждые 100 тыс. населения погибало 13 водителей и пассажиров, а в европейских странах - 2,7. Разрыв увеличился и стал пятикратным (рисунок 19).

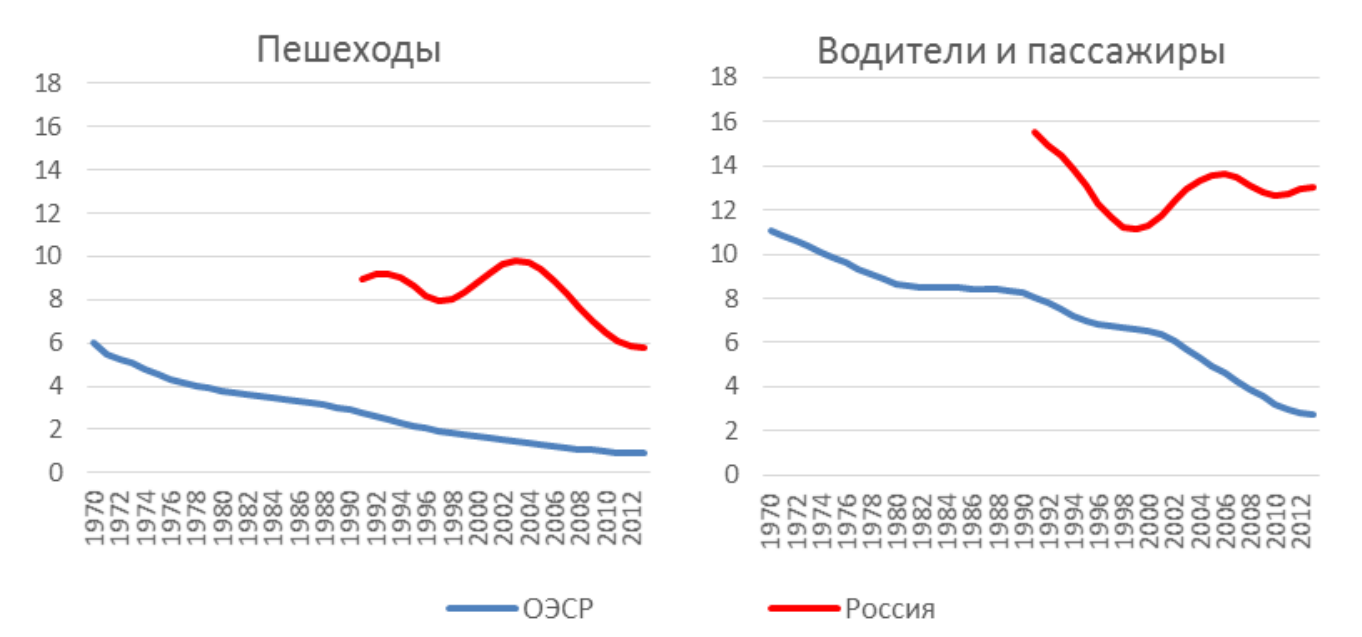

Рисунок 19. Число погибших пешеходов, водителей и пассажиров в России и странах ОЭСР в 1970-2013 гг., на 100 тыс. населения

Источники: [OECD...; ГИБДД...].

Сейчас основная часть пострадавших в европейских и неевропейских странах с низким транспортным травматизмом - водители транспортных средств, доля пешеходов и пассажиров среди погибших невелика, доля пешеходов имеет тенденцию к снижению. В России тоже наблюдается эта тенденция, но пока доля как пешеходов, так и пассажиров среди погибших в ДТП намного выше, чем в странах с более низким транспортным травматизмом. 
Успехи многих европейских стран с относительно низкой смертностью от ДТП во многом связаны с тем, что большинству из них удалось понизить риски для пешеходов. Россия, если и вступила на этот путь, то с большим опозданием. Как уже отмечалось, долгое время здесь самой уязвимой группой пострадавших были именно пешеходы. В 2009 г. по числу погибших они впервые уступили место водителям, но их доля все еще остается очень высокой (рисунок 20).

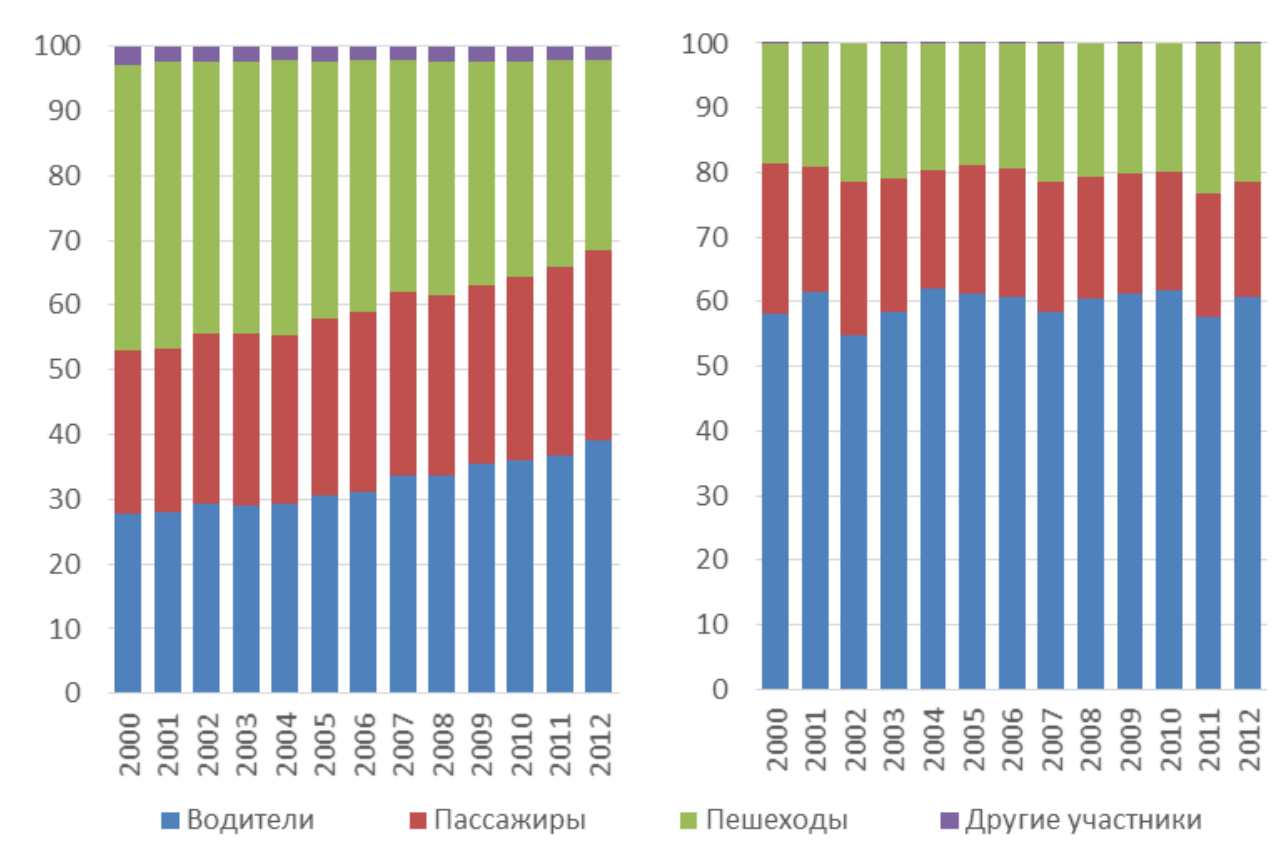

\section{Рисунок 20. Структура погибших в ДТП по категориям участников дорожного движения в России (левая панель) и ЕС-14* (правая панель), 2000-2012 гг.}

* EC-14: Чехия, Дания, Германия, Испания, Франиия, Италия, Люксембург, Нидерланды, Австрия, Польша, Португалия, Румыния, Финляндия, Великобритания.

Источники: [European Road Safety Observatory; ГИБДД...].

В Европе наибольшее снижение смертности от ДТП среди пешеходов в 1991-2012 гг. наблюдалось в таких странах, как Португалия, Венгрия, Польша, Греция. В 2012 г. смертность пешеходов в расчете на 100 тыс. населения была наименьшей в Швеции $(0,3)$, Норвегии $(0,3)$, Нидерландах $(0,4)$, Финляндии $(0,5)$. Наибольшие показатели были зафиксированы в России $(5,8)$, Польше $(3)$, Венгрии $(1,6)$, Чехии $(1,6)$.

Если говорить о смертности защищённых участников дорожного движения (водители и пассажиры) в европейских странах, то с 1991 по 2012 г. наибольшее снижение продемонстрировали такие страны, как Испания, Франция, Австрия, Бельгия, Португалия. Наименьшие показатели смертности защищённых участников дорожного движения в европейских странах в расчете на 100 тыс. населения в 2012 г. наблюдались в Швейцарии $(1,3)$, Великобритании $(1,3)$, Нидерландах $(1,4)$, Норвегии $(1,4)$, Дании $(1,5)$. Наибольшие показатели были зафиксированы в России $(13)$, Греции $(4,2)$, Польше $(4,2)$, Чехии $(3,5)$, Бельгии $(3,5)$. 
Таким образом, несмотря на то, что структура погибших от ДТП сильно варьируется по странам, Россия по-прежнему сохранять абсолютное лидерство в смертности от ДТП для всех категорий участников дорожного движения (рисунок 21).

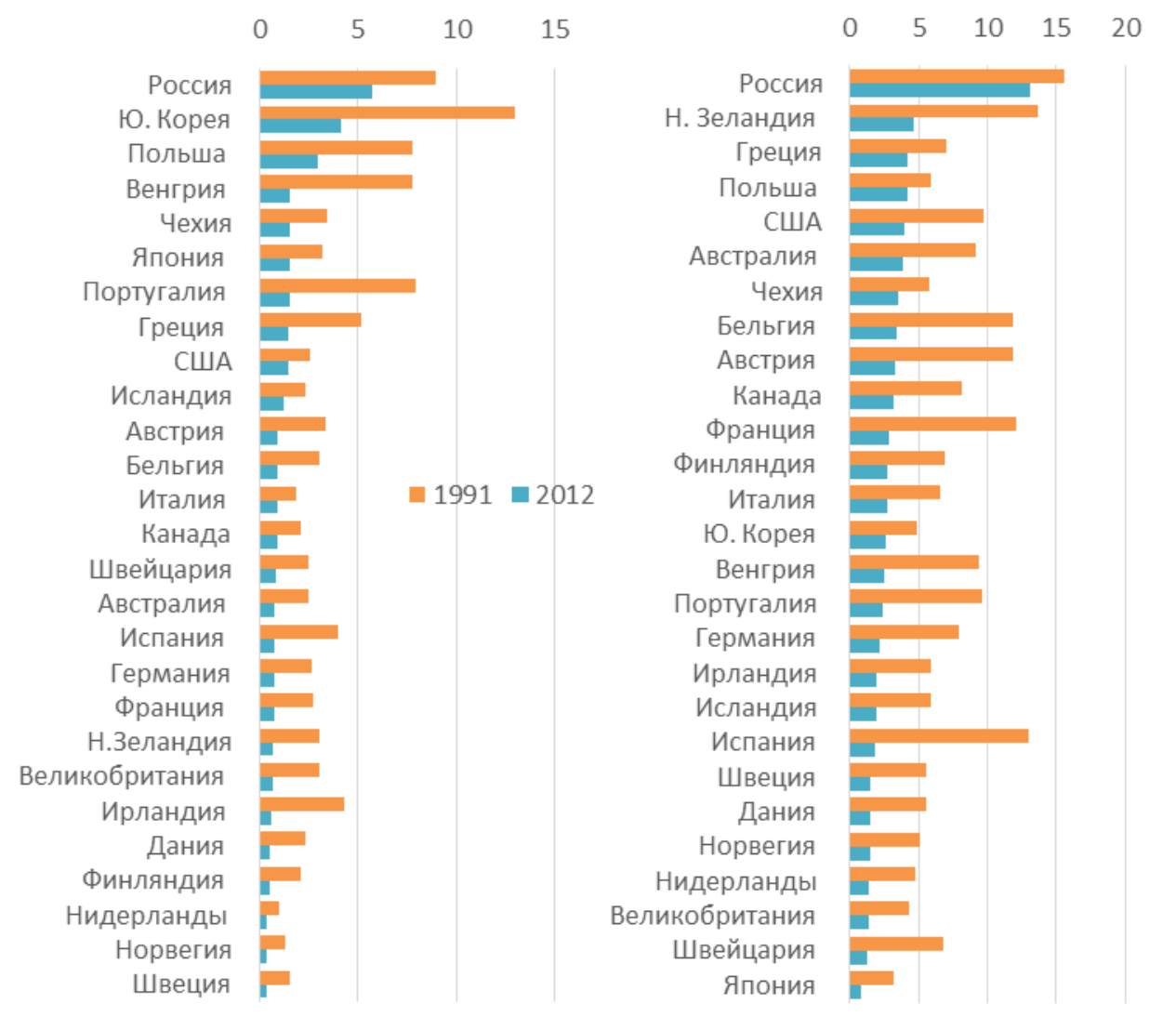

\section{Рисунок 21. Общий коэффициент смертности от ДТП для разных категорий участников дорожного движения в 1991, 2012 г., на 100 тыс. населения}

Источники: [International Road Traffic Accident Database; ГИБДД...].

Возрастная структура смертности у разных групп участников дорожного движения имеет свои особенности. У мужчин наибольшему риску подвергаются молодые водители. Смертность мужчин-пешеходов нарастает с возрастом и достигает пика в пожилых возрастах. Мужчины-пассажиры имеют возрастной профиль смертности, схожий с водителями, но в каждой возрастной группе, за исключением детских возрастов, значение возрастного коэффициента для них ниже.

У женщин возрастная структура смертности для разных категорий участников дорожного движения отличается от мужской. Женщины-пешеходы вносят наибольший вклад в женскую дорожно-транспортную смертность. Профиль кривых смертности для женщин-водителей и пассажиров сходен с мужскими кривыми, но выражен менее ярко (рисунок 22). 


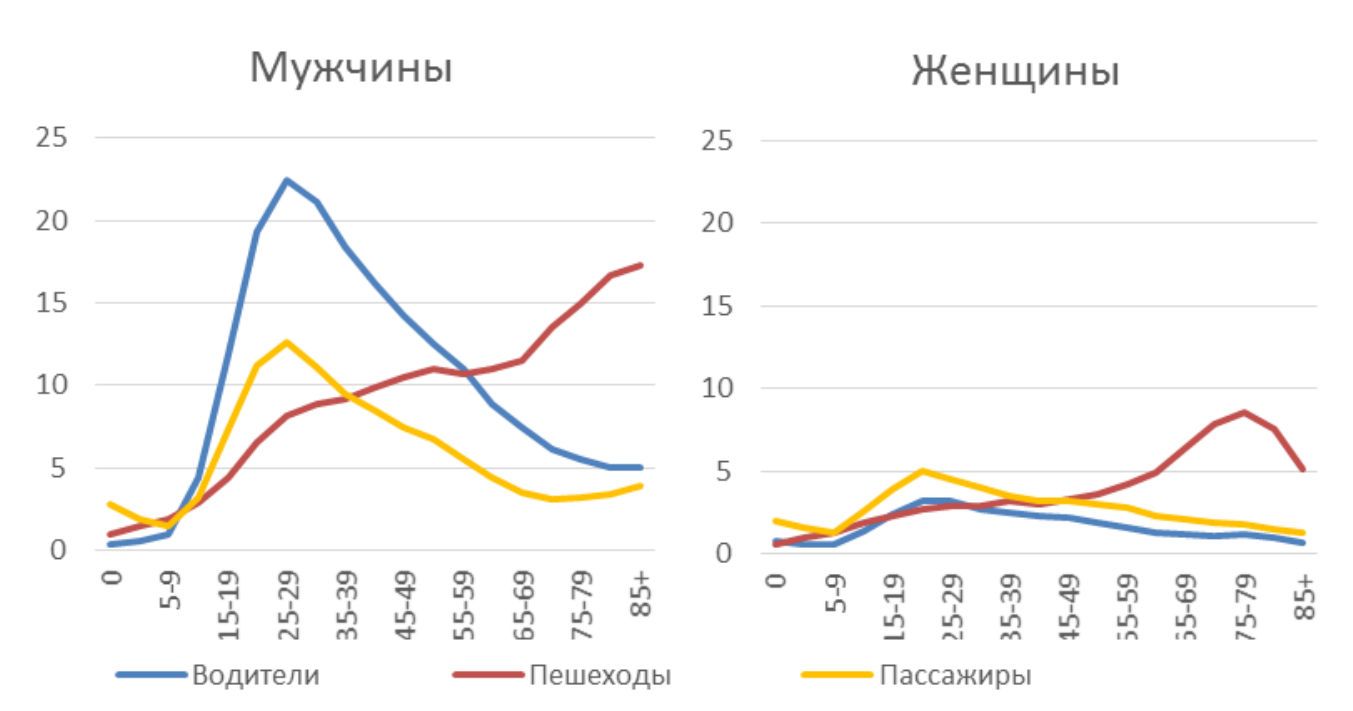

Рисунок 22. Возрастные коэффициенты смертности от ДТП разных участников дорожного движения в России в 2011 г., на 100 тыс. населения

Источники: [International Road Traffic Accident Database], неопубликованнье даннье Росстата.

\section{ЗАКЛЮЧЕНИЕ}

ДТП - очень молодая причина смерти, ей всего чуть больше 100 лет. Но за эту столетнюю историю ДТП успели пройти три стадии развития: «подъем, расцвет и падение». Переход из одного состояния в другое обусловливался сочетанием различных факторов. Так, индустриализация и технический прогресс сделали возможным появление автомобиля. Дальнейшее общественное развитие сделало его частью повседневной жизни со всеми вытекающими из этого последствиями и представлениями о проблеме. В процессе массовой автомобилизации происходит осознание не только позитивных, но и негативных последствий автомобилизации, их причин, меняются взгляды на проблему, идет поиск новых решений. Так как страны Запада первые встали на путь автомобилизации, то и механизмы противодействия им пришлось осваивать первыми, методом проб и ошибок.

Результаты, которые достигнуты в некоторых странах в снижении смертности от ДТП, можно назвать ошеломляющими. Показатель 3-5 погибших на 100 тыс. населения демонстрирует, что ДТП являются практически полностью устранимой причиной смерти.

Россия по уровню транспортного развития сильно отстает от западных стран. Отставание относится не только к общему уровню автомобилизации населения, но и к уровню всего относящегося к автомобильному движению инфраструктурного, правового и административного устройства. Существует недооценка значимости научной деятельности в сфере безопасности дорожного движения, которая имела и продолжает иметь фундаментальное значение на Западе.

Как характеристики общего уровня автомобилизации, так и основные показатели транспортного травматизма, такие как число погибших на 100 тыс. населения, на 10 тыс. транспортных средств или на километраж автопробега, свидетельствуют о том, что Россия по уровню транспортного развития отстает от стран Запада на 40-50 лет. 
Дорожно-транспортный травматизм в России - высоко политизированная проблема. У большинства людей есть собственное, но не очень обоснованное мнение о том, что можно сделать, чтобы дороги стали безопаснее. Фрагментарная информация и ее освещение в СМИ слишком часто трактуют отдельные случаи как крупные проблемы транспортной безопасности, требующие приоритетных мер, на что в свою очередь вынуждены реагировать политики. Но стратегические решения, направленные на эффективное предотвращение дорожно-транспортного травматизма, должны основываться на полной и объективной информации, а не на отдельных сообщениях с мест.

Авторы первой и второй профильных Федеральных целевых программ «Повышение безопасности дорожного движения», проводимых в России, убеждены, что ориентируются на лучшие зарубежные практики. План проводимых в последние годы мероприятий чаще всего направлен на устранение технических недостатков транспортной системы («трясущие полосы», разделительные барьеры, запрет использования мобильных телефонов, применение ремней безопасности на заднем сидении, детские автокресла и др.). Но суть «западных практик» скрывается не в технических деталях, а в правильных институциональных структурах. Транспортные риски есть функция от качества институтов и в первую очередь от института «тотального равенства прав, ответственности и обязанностей всех участников дорожного движения» [Блинкин, Решетова 2013].

Насколько успешно будут в ближайшее время складываться тенденции в смертности от ДТП в России, во многом зависит от желания осознать и всесторонне изучить проблему. Без этого, без систематических научных исследований и регулярных публикаций по проблемам ДТП невозможна разработка взвешенных и адекватных рекомендаций и решений в вопросах безопасности дорожного движения. Принятие же случайных, нередко импульсивных решений, только загоняет болезнь внутрь.

\section{ЛИТЕРАТУРА}

Базы данных OOH. URL: http://www.un.org/ru/databases/ (дата обращения 12.07.2015).

Библия. Вторая книга Маккавейская 9:7. URL: http://rusbible.ru/sinodal/2makk.9.html\#r2makk-9 (дата обращения 12.07.2015).

Блинкин М. Я., Е.М. Решетова (2013). Безопасность дорожного движения: история вопроса, международный опыт, базовые институции. М.: Высшая школа экономики.

Васин С.А., А. Кренев (2012). «Род смерти не установлен» - ведущая причина насильственной смертности в России // ДемоскопWeekly. № 535 - 536. URL: http://demoscope.ru/weekly/2012/0535/analit010.php (дата обращения 12.07.2015).

Вишневский А.Г. (2010). Сбережение народа или депопуляция России? Москва: Издательский дом Государственного университета Высшей школы экономики. URL: https://www.hse.ru/data/2010/04/07/1218109061/vishnevski.pdf (дата обращения 12.07.2015).

Вишневский А.Г., Т.А. Фаттахов (2012). ДТП и смертность в России // Демоскоп Weekly. №527-528. URL: http://demoscope.ru/weekly/2012/0527/tema01.php (дата обращения: 27.07.2015). 
ГИБДД. Официальный сайт. URL: http://www.gibdd.ru/stat/ (дата обращения 03.07.2015).

Долматовский Ю.А. (1986). Автомобиль за 100 лет. Москва: Знание. URL: http://bibliotekar.ru/auto2/index.htm (дата обращения 10.07.2015).

Золотая книга Госавтоинспекции 1936-2006 гг. (2006). Том 1. Москва: Научноиздательское предприятие "2P".

Кулишер И.М. (2012). История экономического быта Западной Европы. Москва: Социум.

Марциал Марк Авлерий (1968). Эпиграммы. Москва: Художественная литература: 12.

Международная статистическая классификация болезней и проблем, связанных со здоровьем. 1-10 редакция. URL: http://www.wolfbane.com/icd/index.html (дата обращения 10.07.2015).

Милле Ф., В.М. Школьников, В. Эртриш, Ж. Валлен (1996). Современные тенденции смертности по причинам смерти в России, 1965-1994. Paris: INED. URL: http://demoscope.ru/weekly/knigi/shkol/shkol.html (дата обращения 10.07.2015).

Народное хозяйство СССР (1958-1990). Статистический ежегодник. Москва: ЦСУ СССР. URL: http://istmat.info/node/21341 (дата обращения 12.07.2015).

Общественный доклад о состоянии дел в сфере организации и безопасности дорожного движения в регионах России 2014 (2014). URL: https://www.oprf.ru/ru/documents/498/1849/newsitem/23992?PHPSESSID=9fgadmd9k11dr eintpa0fgqm41 (дата обращения: 27.07.2015

О федеральной целевой программе "Повышение безопасности дорожного движения в 2013 - 2020 годах". Постановление Правительства РФ от 06.11.2014 №1167. URL: http://www.fcp-pbdd.ru/about_program/index.php (дата обращения: 27.06.2015).

Ревич Б., К. Решетников (2001). Россияне под колесами автомобиля //Демоскоп Weekly. №2. URL: http://demoscope.ru/weekly/002/tema02.html (дата обращения 12.07.2015).

Росстат (1980-2013). Российский статистический ежегодник. Статистический сборник.

Росстат (1990-2013). Транспорт в России. Статистический сборник.

Росстат (1991-2013). Россия в цифрах. Статистический сборник.

Росстат (1995-2013). Основные показатели транспортной деятельности в России. Статистический сборник.

Росстат (1997-2013). Социальное положение и уровень жизни населения России. Статистический сборник.

Росстат (2000-2013). Транспорт и связь в России. Статистический сборник.

Росстат (2006-2013). Демографический ежегодник России. Статистический сборник.

Сергеенко M.Е. (2000). Жизнь древнего Рима. CПб. URL: http://ancientrome.ru/publik/article.htm? $\mathrm{a}=1291878817$ (дата обращения 03.07.2015).

Фаттахов Т.А. (2014). Пешеходы на дорогах //Демоскоп Weekly. №603-604. URL: http://demoscope.ru/weekly/2014/0603/tema01.php (дата обращения: 27.07.2015).

Форма №57 "Сведения о травмах, отравлениях и некоторых других последствиях воздействия внешних причин" (2011). Росстат.

Форма №7-собес "Распределение впервые признанных инвалидами по формам болезней, возрасту и группам инвалидности" (2012). Росстат. 
Ювенал (2015). Сатиры. URL: http://www.ancientrome.ru/antlitr/juvenal/juvenal3.html (дата обращения 12.07.2015).

Cummins G. (2003). The History of Road Safety. URL:

http://www.driveandstayalive.com/Info\%20Section/history/history.htm (дата обращения 27.07.2015).

Derriks H.M., P.M. Mak (2007). IRTAD special report, underreporting of road traffic casualties // Public Works and Water management. The Netherlands: Ministry of Transport.

European Road Safety Observatory. URL:

http://ec.europa.eu/transport/road_safety/specialist/erso/index_en.htm (дата обращения 27.07.2015).

International Road Traffic Accident Database (IRTAD). URL:

http://www.swov.nl/NL/Research/cijfers/Cijfers_Internationaal.htm (дата обращения 27.07.2015).

Meslé F., J. Vallin, V. Hertrich, E. Andreev, V. Shkolnikov (2003). Causes of death in Russia: assessing trends since the 1950s // European Population Conference «Population of Central and Eastern Europe. Challenges and Opportunities» / Ed. by I.E. Kotowska and J. Józwiak. Warsaw: Statistical Publishing Establishment. См. также http://demoscope.ru/weekly/knigi/epc.php

Morris E. (2007). From Horse Power to Horsepower. URL: http://www.uctc.net/access/30/Access\%2030\%20-\%2002\%20-\%20Horse\%20Power.pdf (дата обращения 27.07.2015).

OECD. Stat. URL: http://stats.oecd.org/ (дата обращения 27.07.2015).

WHA27.59. Prevention of road traffic accidents. Twenty-seventh World Health Assembly Geneva, 7-23 may 1974.

http://who.int/violence_injury_prevention/resources/publications/en/WHA2759_eng.pdf?ua= $1 \& u a=1$

WHO Mortality Database (MDB). URL: http://www.who.int/healthinfo/mortality_data/en/ (дата обращения 27.07.2015). 


\section{ROAD TRAFFIC ACCIDENTS AND MORTALITY IN RUSSIA TIMUR FATTAKHOV}

Fattakhov Timur Asfanovich. Institute of Demography, National Research University Higher School of ECONOMICS. E-MAIL: tfattahov@hse.ru. DATE RECEIVED: February 2015.

The article presents for the first time an analysis of the continuous statistical data series on deaths from road accidents in Russia since 1956. The total number of deaths for 1956-2012 exceeded 1.4 million. The increase in mortality from traffic accidents started in the 1970s; since the beginning of the 1990s the lag behind most developed countries has been growing. At 2012 mortality levels about 85-95\% of Russia's deaths from road accidents were excessive compared with the number of deaths that would have occurred at age-specific mortality rates from this cause in selected European countries. Both the current characteristics of the general level of motorization and the main indicators of traffic injuries, such as the number of deaths per 100 thousand persons, per 10 thousand vehicles or per number of kilometers traveled, show that in terms of transport development Russia lags 40-50 years behind Western countries.

The article also examines the history of the inclusion of mortality from road accidents in the International Classification of Causes of Death (ICD) and the problems of reflecting this mortality in Russian mortality statistics.

Gender-specific features and trends in Russian mortality from traffic accidents are analyzed, as well as the differences in mortality for different categories of road users (drivers, passengers and pedestrians) for the maximum possible time period. International comparisons that allow understanding the extent of Russian backwardness and seeing the long-term unsustainable trends in mortality from road accidents are presented.

A conclusion is made concerning the need to expand research into the problems of road safety, indispensable for developing effective programs that enhance safety and for catching up with the many countries ahead of Russia.

Key words: motorization; traffic accidents; history of traffic accidents; deceased in an accident; ICD; external causes of death.

\section{REFERENCES}

Bazy dannyh OON. [Database of the United Nations]. URL: http://www.un.org/ru/databases/ (accessed 07.12.2015).

Biblija. Vtoraja kniga Makkavejskaja 9:7 [The Bible. The Second Book of Maccabees 9:7]. URL: http://rusbible.ru/sinodal/2makk.9.html\#r-2makk-9 (accessed 12.07.2015).

Blinkin M.Ja., E.M. Reshetova (2013). Bezopasnost' dorozhnogodvizhenija: istorijavoprosa, mezhdunarodnyjopyt, bazovyeinstitucii [Road-traffic safety: history of the question, international experience, and basic institutes]. M.: Vysshaja shkola jekonomiki.

Cummins G. (2003). The History of Road Safety. URL:

http://www.driveandstayalive.com/Info\%20Section/history/history.htm (accessed 27.07.2015).

Derriks H.M., P.M. Mak, (2007). IRTAD special report, underreporting of road traffic casualties. Public Works and Water management. The Netherlands: Ministry of Transport.

Dolmatovskij Ju.A. (1986). Avtomobil' za 100 let [Car for 100 years]. Moskva: Znanie. URL: http://bibliotekar.ru/auto2/index.htm (accessed 10.07.2015).

European Road Safety Observatory. URL:

http://ec.europa.eu/transport/road_safety/specialist/erso/index_en.htm (accessed 27.07.2015). 
Fattahov T.A. (2014). Peshehody na dorogah [Pedestrians on the road] // Demoskop Weekly. №603-604. URL: http://demoscope.ru/weekly/2014/0603/tema01.php (accessed: 27.07.2015).

Forma №57 "Svedenija o travmah, otravlenijah i nekotoryh drugih posledstvijah vozdejstvija vneshnih prichin" [Information on injuries, poisonings and certain other consequences of external causes] (2011). Rosstat.

Forma №7-sobes "Raspredelenie vpervye priznannyh invalidami po formam boleznej, vozrastu i gruppam invalidnosti" [The distribution of new cases of disability in forms of disease, age and disability groups] (2012). Rosstat.

GIBDD. Oficial'nyj sajt [Traffic police. official site]. URL: http://www.gibdd.ru/stat/ (accessed 03.07.2015).

International Road Traffic Accident Database (IRTAD). URL: http://www.swov.nl/NL/Research/cijfers/Cijfers_Internationaal.htm (accessed 27.07.2015).

Juvenal (2015). Satiry. URL: http://www.ancientrome.ru/antlitr/juvenal/juvenal3.html (accessed 12.07.2015).

Kulisher I.M. (2012). Istorija jekonomicheskogo byta Zapadnoj Evropy [History of the economic life of Western Europe]. Moskva: Socium.

Marcial Mark Avlerij (1968). Jepigrammy [Epigrams]. Moskva: Hudozhestvennaja literatura.

Meslé F., J. Vallin, V. Hertrich, V. Shkolnikov (1996). Sovremennye tendencii smertnosti po prichinam smerti v Rossii 1965-1994 [Modern trends in mortality by cause of death in Russia, 1965-1994.]. Paris: INED. URL: http://demoscope.ru/weekly/knigi/shkol/shkol.html (accessed 10.07.2015).

Meslé F., J. Vallin, V. Hertrich, E. Andreev., V. Shkolnikov (2003). Causes of death in Russia: assessing trends since the 1950s / European Population Conference «Population of Central and Eastern Europe. Challenges and Opportunities» Ed. by Irena E. Kotowska and J. Józwiak. Warsaw: Statistical Publishing Establishment.

Mezhdunarodnaja statisticheskaja klassifikacija boleznej i problem, svjazannyh so zdorov'em. 110 redakcija [International Statistical Classification of Diseases and Related Health. 1-10 edition.]. URL: http://www.wolfbane.com/icd/index.html (accessed 10.07.2015).

Morris E. (2007). From Horse Power to Horsepower. URL: http://www.uctc.net/access/30/Access \%2030\%20-\%2002\%20-\%20Horse\%20Power.pdf (accessed 27.07.2015).

Narodnoe hozjajstvo SSSR (1958-1990). Statisticheskij ezhegodnik [The national economy of the USSR (1958-1990). Anniversary statistical yearbook]. Moskva: CSU SSSR; 1958-1990 URL: http://istmat.info/node/21341 (accessed 12.07.2015).

Obshhestvennyj doklad o sostojanii del v sfere organizacii I bezopasnosti dorozhnogo dvizhenija $\mathrm{v}$ regionah Rossii 2014 [The public report on the state of affairs in the organization and road safety in the Russian regions 2014]. URL:

http://os.mvd.ru/upload/site107/doklad_bezopasnost_dorozhnogo_dvizheniya03122013.pdf (accessed 27.07.2015).

OECD. Stat. URL: http://stats.oecd.org/ (accessed 27.07.2015).

O federal'noy tselevoy programme "Povyshenie bezopasnosti dorozhnogo dvizheniya v 2013 -

2020 godakh". [On the federal target program "Improvement of road safety in 2013 - 2020"]. 
Postanovlenie Pravitel'stva RF ot 06.11.2014 №1167. URL: http://www.feppbdd.ru/about_program/index.php (accessed 12.07.2015).

Revich B., K. Reshetnikov (2001). Rossijane pod kolesami avtomobilja [Russians under the wheels of a car] // Demoskop Weekly. №2. URL: http://demoscope.ru/weekly/002/tema02.html (accessed 12.07.2015).

Rosstat (1980-2013). Rossijskij statisticheskij ezhegodnik. [Federal State Statistics Service (1980-2013)]. Statisticheskij sbornik.

Rosstat (1990-2013). Transport v Rossii. [Transportation in Russia (1990-2013)]. Statisticheskij sbornik.

Rosstat (1991-2013). Rossija v cifrah [Russia by the Numbers (1991-2013)]. Statisticheskij sbornik.

Rosstat (1995-2013). Osnovnye pokazateli transportnoj dejatel'nosti v Rossii. [Main indicators of transport in Russia (1995-2013)]. Statisticheskij sbornik.

Rosstat (1997-2013). Social'noe polozhenie i uroven' zhizni naselenija Rossii. [Social status and standard of living of the Russian population (1997-2013)]. Statisticheskij sbornik.

Rosstat (2000-2013). Transport i svjaz' v Rossii. [Transport and communications in Russia (2000-2013)]. Statisticheskij sbornik.

Rosstat (2006-2013). Demograficheskij ezhegodnik Rossii. [Demographic Yearbook of Russia (2006-2013)]. Statisticheskij sbornik.

Sergeenko M. E. (2000). Zhizn' drevnego Rima [The life of ancient Rome.]. SPb. URL: http://ancientrome.ru/publik/article.htm?a=1291878817 (accessed 03.07.2015).

Vasin S.A., A. Krenev (2012). "Rod smerti ne ustanovlen" - vedushhaja prichina nasil'stvennoj smertnosti v Rossii ["Rod's death is not installed" - the leading cause of violent deaths in Russia] // Demoskop Weekly. № 535 - 536. URL: http://demoscope.ru/weekly/2012/0535/analit010.php (accessed 12.07.2015).

Vishnevskij A.G. (2010). Sberezhenie naroda ili depopuljacija Rossii? [Saving people depopulation or Russia?]. Moskva: Izdatel'skij dom Gosudarstvennogo universiteta Vysshejshkoly jekonomiki. URL: https://www.hse.ru/data/2010/04/07/1218109061/vishnevski.pdf (accessed 12.07.2015).

Vishnevskij A.G., T.A. Fattahov (2012). DTP ismertnost' v Rossii [Road traffic accidents and deaths in Russia] // Demoskop Weekly. №527-528. URL: http://demoscope.ru/weekly/2012/0527/tema01.php (accessed 27.07.2015).

WHA27.59. Prevention of road traffic accidents. Twenty-seventh World Health Assembly Geneva, 7-23 may 1974.

http://who.int/violence_injury_prevention/resources/publications/en/WHA2759_eng.pdf?ua= $1 \& u a=1$

WHO Mortality Database (MDB). Available from: http://www.who.int/healthinfo/mortality_data/en/ (accessed 27.07.2015).

Zolotaja kniga Gosavtoinspekcii 1936-2006 (2006). [The Golden Book of traffic police 19362006]. Tom 1. Moskva: Nauchno-izdatel'skoe predprijatie "2R". 